\title{
Conditions of landslide development during the last decade in the Rożnów Dam-Lake region (Southern Poland) based on Airborne Laser Scanning (ALS) data analysis
}

\author{
Marcin WÓDKA ${ }^{1, *}$ \\ 1 Polish Geological Institute - National Research Institute, Geohazards Centre, Skrzatów 1, 31-560 Kraków, Poland
}

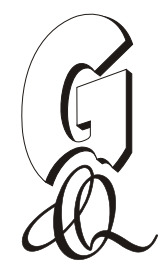

\begin{abstract}
Wódka, M., 2022. Conditions of landslide development during the last decade in the Rożnów Dam-Lake region (Southern Poland) based on Airborne Laser Scanning (ALS) data analysis. Geological Quarterly, 66: 4, doi: 10.7306/gq.1636

In order to identify the causes of landslide development in the area of Rożnów Lake (Outer Carpathians - southern Poland) in the last decade, Differential Digital Terrain Models (DDM) were used. These were made on the basis of Airborne Laser Scanning (ALS) data from four flights. The first ALS data are from 2010, before the event in Poland known as the "landslide catastrophe". Comparing digital terrain models from different years tracking of changes in landslide activity relative to the intensity of precipitation. The article presents a method of investigating landslides with the use of DDM. This analysis allowed calculation of the displacement lithological index and of landslide susceptibility, based only on landslides that have become active in the last decade. The areas with the highest susceptibility to landslides are regions of Hieroglyphic Beds occurrence and of tectonic overthrusts. An important role in the development of landslides in the area of Rożnów Lake is also played by the thick-bedded Ciezżkowice sandstones (usually associated with low susceptibility to landslides). After the "landslide catastrophe", it is precisely in these formations that the greatest displacements and more frequent widening of the landslide boundaries were recorded, though they are generally stable during smaller rainfall.
\end{abstract}

Key words: landslides, mass movements, Differential Digital Terrain Models, geohazards, Rożnów Dam-Lake region, Outer Carpathians.

\section{INTRODUCTION}

Prolonged rainfall in late May and early June 2010 led to the activation of many landslides in the Polish Carpathians. This event is known in Poland as a "landslide catastrophe". At that time, in the area of Lake Rożnów, much infrastructure was damaged. In extreme cases, such as in Kłodne (Limanowa borough), the destruction affected several dozen buildings within one landslide (Wójcik et al., 2012; Perski et al., 2014). Between May 15 and June 4, 2010, according to date of the Institute of Meteorology and Water Management, from the nearest measurement station in Limanowa, $381 \mathrm{~mm}$ of rain fell; at the beginning of June, rainfall remained intense and with daily totals exceeding $64 \mathrm{~mm}$. In addition, the annual rainfall at the measuring station in Nowy Sącz was the highest in 130 years. Many landslides have not reached a new equilibrium state to this day and are still active.

The occurrence of landslides and their activity are conditioned by a set of factors that affect slope stability (Bober, 1984; Dikau et al., 1996; Zabuski et al., 1999; Pradhan et al., 2010b; Lee et al., 2017). These are passive factors such as geological structure, slope morphology, land use or distance from the river network, and active factors such as precipitation, seismic

\section{*E-mail: marcin.wodka@pgi.gov.pl}

Received: October 26, 2021; accepted: December 30, 2021; first published online: February 8, 2022 shocks, river erosion and anthropopressure. In Poland, the most common cause of the activation of landslides is long-term rainfall (Ziętara, 1974; Starkel, 1996; Gil, 1997).

With the advent of Airborne Laser Scanning (ALS) data, it became possible to create high-resolution Digital Terrain Models (DTM). These models are generated from huge point clouds, which, after appropriate classification, provide information about the land surface, separate from data on its cover (buildings, vegetation; Glenn et al., 2006).

Repeated aerial surveys of the same area allow the calculation of Differential Digital Terrain Models (DDM). These illustrate altitudinal differences between DTMs that may have arisen between the flights (Borkowski et al., 2012). By this means, it is possible to constrain the activity of landslides and to track changes in the dynamics of displacements, making it possible to confirm or reject the often subjective field assessments of landslide activity.

The present research was carried out to determine the causes of the activation of landslides in 2010 and later in the area of Rożnów Lake, based on the analysis of differential models obtained from the ALS data.

\section{GEOLOGICAL AND GEOMORPHOLOGICAL SETTING}

The research was conducted within the Outer Carpathians (Żytko et al., 1989; Ślączka et al., 2006) between Czchów and Nowy Sącz (Fig. 1). The area analysed covers $128 \mathrm{~km}^{2}$; not 


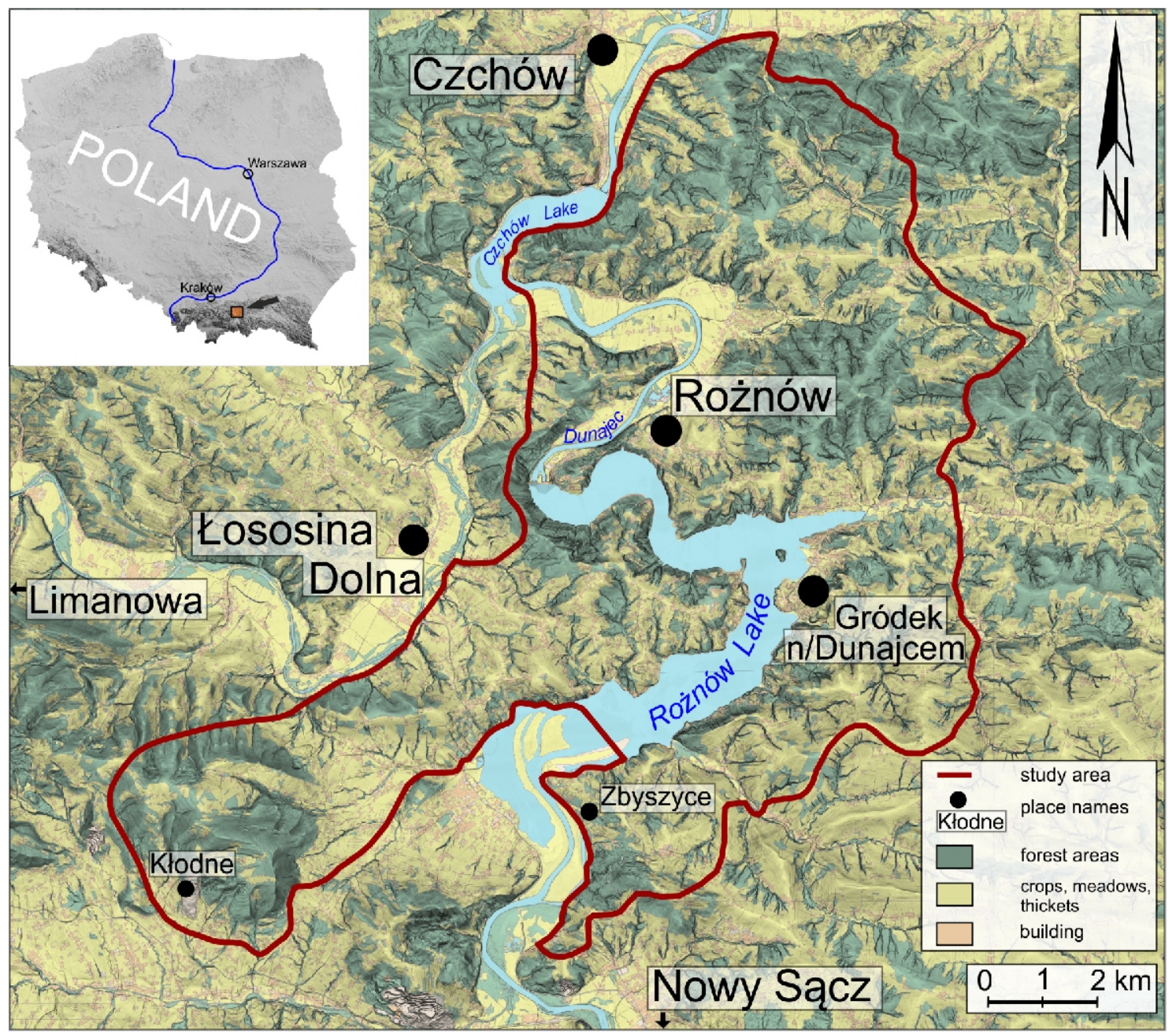

Fig. 1. Location of the study area (arrow on the map of Poland shows the study area)

counting the flat bottom of the Dunajec valley (not affected by landslide processes), is $112 \mathrm{~km}^{2}$.

Most of the research area consists of narrow hills 350-450 m a.s.l. cut by the Dunajec valley and its tributaries. These cuts are up to 100-150 m deep. The elongated ridges have convex-concave slopes, most typically of $6-18^{\circ}$ and modeled by water erosion and mass movements (Ziętara, 1974). Slopes that are SW (25\%), NE (24\%), NW (22\%) and SE (19\%) facing predominate.

In the southwestern part of the research area, Chełm Hill has the highest elevation in the area analysed (789 $\mathrm{m}$ a.s.I.). It is a clearly marked, isolated feature with steep northern slopes (20-24 slope) and gentler, longer southern slopes ( $12^{\circ}$ slope).

Along the Dunajec valley there is a system of Pleistocene and Holocene river terraces of various ages (Zuchiewicz, 1990). In this valley, just next to the northern border of the study area, there is the lowest point of the area analysed (221 m a.s.I.).

The study area is underlain by flysch rocks of Cretaceous and Paleogene age (Burtan and Skoczylas-Ciszewska, 1964; Cieszkowski et al., 1987; Burtan et al., 1991; Paul, 1997).

The predominant northern and central part of the area belongs to the Silesian Nappe (Fig. 2). The southwestern part of the area is made up of sedimentary rocks of the Magura Nappe and the Michalczowa Nappe (Cieszkowski, 1992). A small, southern part of the area belongs to the Grybów Nappe (Fig. 2).
In the study area, Quaternary deposits of various origins are exposed in the bottom of the valleys and in the lower sections of the slopes. These comprise fluvial, organogenic, loess, landslide, deluvial and weathered deposits.

The Rożnów-Ciężkowice anticline runs through the central part of the research area, in the core of which the oldest rocks in this area are exposed: sandstones of the Godula Beds. There are extensive outcrops of sandstones and conglomerates of the Lower Istebna Beds, sandstones and shales of the Hieroglyphic Beds, and sandstones and shales of the Krosno Beds. The highest peaks are located in the southwestern part of the area and are built of thick-bedded Magura sandstones. Significant geological structures include faults and overthusts (Fig. 2).

The area around Rożnów Lake has a considerable surface landslide cover, of $17.2 \%$; excluding the flat Dunajec valley from the calculations, nearly $1 / 5$ of the study area is covered by landslides. Based mainly on the archival materials available in the database (SOPO) of the Polish Geological Institute, 1275 landslides have been recorded here. The dominant type of mass movement comprises complex slides (cf. Varnes, 1978; Cruden and Varnes, 1996; Dikau et al., 1996; Zabuski et al., 1999), with a predominance of rotational displacements. Rather fewer landslides were classified as translational slides. These are usually shallower structural landslides, the movement of which is consistent with the structure of the rock layers, e.g. the Przydonica landslide. 


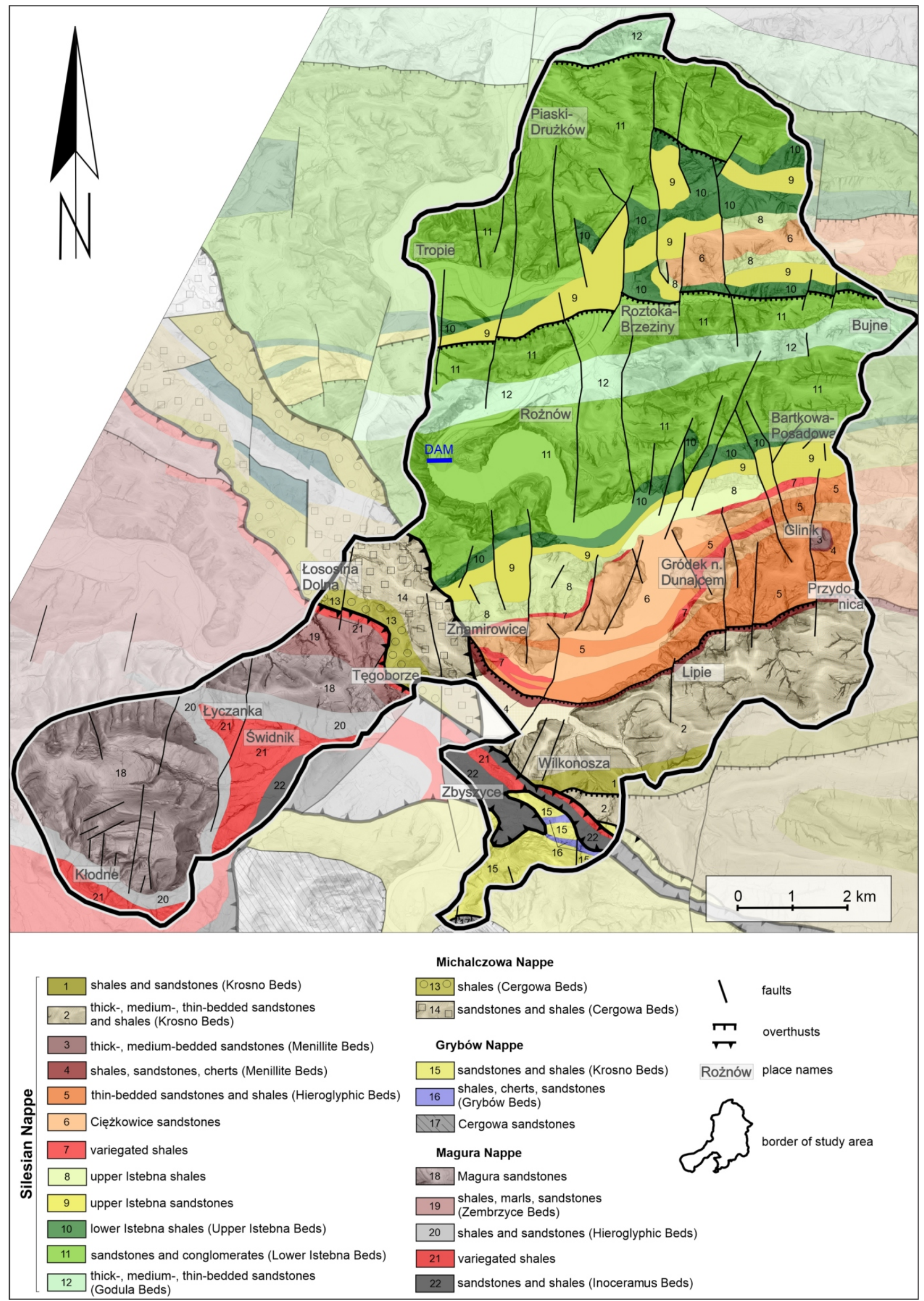

Fig. 2. Geological map of the research area (based on Burtan and Skoczylas-Ciszewska, 1964; Cieszkowski et al., 1987; Burtan et al., 1991; Paul, 1997, amended) 
Landslides where only rotational displacements can be distinguished are few. These are limited to small forms ( $<1$ ha) developed in flysch with a large predominance of shales. Usually their main scarps have a semicircular shape (vide Margielewski, 2004). The are also a few landslides developed in the form of earthflows or debris flows. Movements of this type are developed mainly on the slopes descending directly towards Rożnów Lake.

Least developed are rockfalls, recorded only in a few landslides developed in the Ciężkowice sandstones and in the area of the "Rożnów Rocks", built of Lower Istebna sandstones.

\section{STUDIES OF LANDSLIDES USING ALS DATA}

ALS data has been used to study landslides for nearly 20 years. One of the first attempts to analyse landslides based on DTMs generated from ALS data was by Carter et al. (2001), who, in addition to recording sinkholes in Florida, designated landslides and the places of their potential occurrence. The following years saw further such publications (e.g., McKean and Roering, 2004; Schulz, 2004; Ardizzone et al., 2007; Van den Eeckhaut et al., 2007; Razak et al., 2011; Jaboyedoff et al., 2012; Sutinen et al., 2014; Chiu et al., 2015; Petschko et al., 2016; Brezny and Panek, 2017).

Successive ALS flights have been undertaken to monitor the activity of landslides and to track surface deformation based on differential analyses of terrain models. Such analyses have been carried out in many parts of the world (e.g., Burns et al., 2010; Mickelson, 2011; Daehne and Corsini, 2012; Ventura et al., 2013; Lato et al., 2014; Verbovsek et al., 2017; Mora et al., 2018).

One of the first published studies involving ALS data in the area of Rożnów Dam-Lake was by Borkowski et al. (2011). ALS data applied to a landslide in Zbyszyce was also described by Wojciechowski et al. (2012). Differential models of landslides in Wola Kurowska and landslides on the Just Hill in Tęgoborze were included in an atlas of landslides in the Małopolskie Voivodeship (Chowaniec et al., 2012). LIDAR was also used to study landslide dynamics in Kłodne (Perski et al., 2014). Based on the data obtained from DTMs, the susceptibility to landslides was calculated in the area of Gródek nad Dunajcem (Wojciechowski and Pyrc, 2016) and in the area between Łososina Dolna and Rożnów (Pawłuszek and Borkowski, 2017a). ALS data was also used to attempt to automatate landslide detection in the area of Rożnów Lake by means of supervised classification, with so-called support vectors (Pawłuszek and Borkowski, 2017b, 2020; Pawłuszek-Filipiak and Borkowski, 2020).

\section{DATA AND METHODS}

The research methodology is shown in Figure 3. The first stage of the work was to recognize all landslides in the research area. Many methods of cataloguing landslide forms have been described (e.g., van Westenet al., 2008; Galli et al., 2008; Guzzetti et al., 2012). Determination of the extent of landslides is based on field observations and identification of land relief elements characteristic of landslides. It is usually preceded by analyses of topographic contours, aerial photos (orthophotomaps), high-resolution DTMs and all archival materials, including maps of landslides at 1: 10,000 scale (Jodłowski et al., 2010; Wieczorek et al., 2010; Jurys et al., 2011; Bąk et al., 2011; Koluch and Nowicka, 2012; Wójcik et al., 2015). On the basis of orthophotomaps, DTM analyses and fieldwork, the ex-

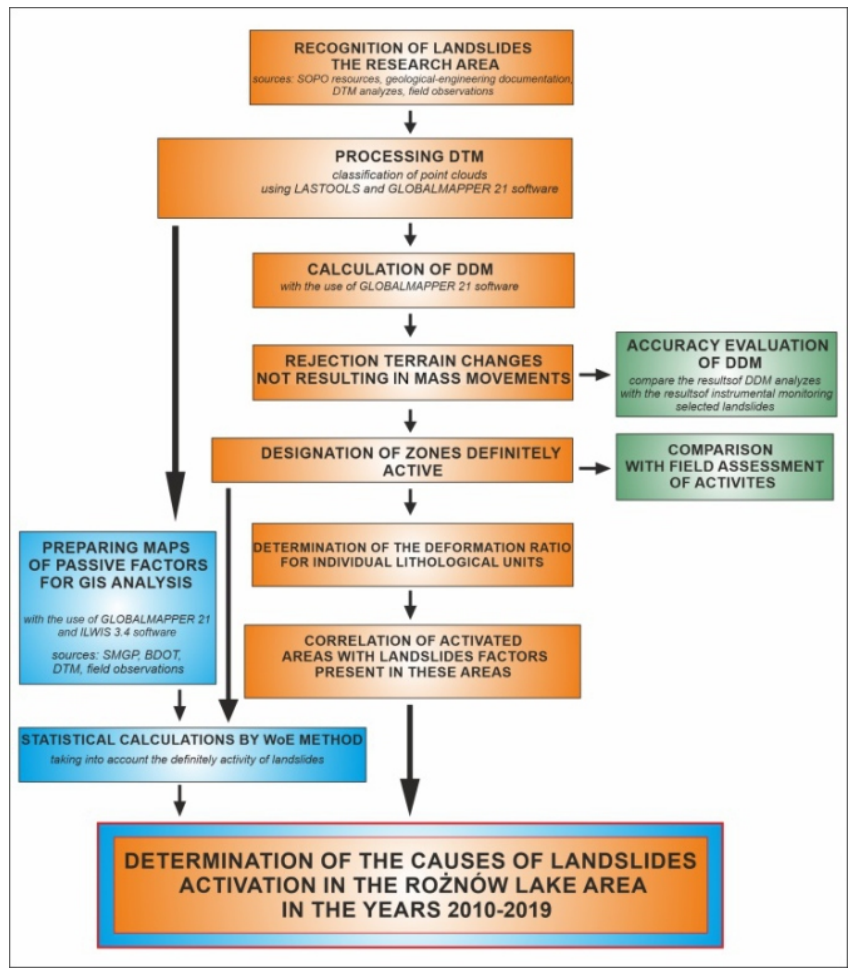

Fig. 3. Diagram of activities involved in the research

tents of previously identified landslides have been clarified and nearly 200 new examples have been documented.

\section{DIFFERENTIAL ANALYSIS OF DTMS}

The research was based on DTMs generated from point clouds obtained by Airborne Laser Scanning. The research used:

- a DTM with a resolution of $1 \times 1$ created from ALS data from April 1, 2010, commissioned by the Wrocław University of Environmental and Life Sciences (Borkowski et al., 2011; Wojciechowski et al., 2012) with an average density of 7 laser points $/ \mathrm{m}^{2}$. The flights covered the southeastern part of the research area (Fig. 4);

- a DTM with a resolution of $1 \times 1$ made for the IT System of Country Protection project (ISOK), using data from 2011 (northern part of the research area) and 2013 (southern part of the research area) with an average density of 4 points $/ \mathrm{m}^{2}$, although in the area of some landslides, the point density was up to 9 points $/ \mathrm{m}^{2}$ (e.g., the landslide area in Zbyszyce). The flights covered the entire research area (Fig. 4);

- a DTM with a resolution of $1 \times 1$ commissioned by the Polish Geological Institute - National Research Institute (PGI-NRI) from the 2018 and 2019 flights. Scanning was performed with an average resolution of 8 points $/ \mathrm{m}^{2}$ and 7 points $/ \mathrm{m}^{2}$, respectively. The flights covered $\sim 70 \%$ of the research area (Fig. 4).

LasTools and GlobalMapper software were used to classify the point cloud, using the automatic classification functions and manual correction of selected points, so that the DTMs were burdened with the fewest errors and visually as close to each other as possible. Filtered points were interpolated in the shape of triangles (TIN). 


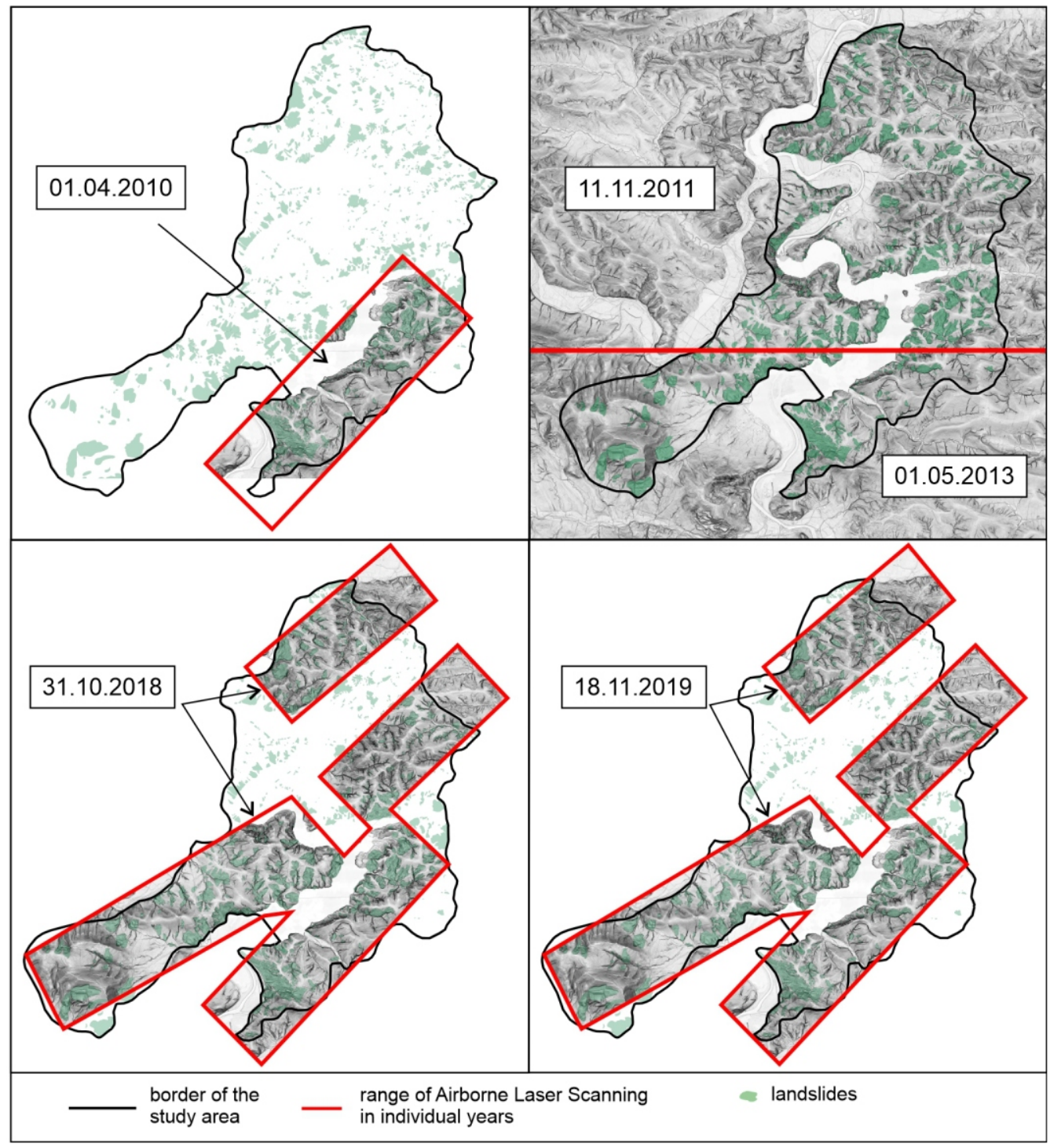

Fig. 4. The range of Airborne Laser Scanning in individual years in the study area

An important element was the determination of landslide activity in the last decade. DDMs served this purpose. They were obtained by comparing data from at least two ALS flights carried out over the same site, at different times. The DDM is the result of subtracting the new DTM altitude value from that of generated on the basis of the older flight data, in the same data georeference (Borkowski et al., 2012). The "Combine/CompareTerrainLayers" function in the Global Mapper 21 software was used to generate differential images of the study area.

After obtaining the differential models, a displacement analysis was performed for each of the landslides, eliminating changes that occurred as a result of anthropogenic activity, river erosion and accumulation, or are the result of differences in the quality of ALS data or data filtering errors. DTMs from a given period, historical aerial photos available in Google Earth Pro and information contained in landslide registration cards were used to analyse the changes. The filtered differential models were compared with the results of instrumental monitoring of selected landslides conducted by the PGI-NRI, which allowed determination of their accuracy at $\sim 25-30 \mathrm{~cm}$. The determination of unambiguously active zones was of significant importance at further stages of the work and allowed assigning of higher landslide-forming values to environmental factors occurring in these areas.

Using the Global Mapper software, the volume between the surfaces of individual DTMs within the landslides was calculated, excluding the anthropogenically modified areas. The values obtained values did not define the volume of the landslide colluvium, but indicated the scale of changes that occurred at the ground surface as a result of mass movements. In order to determine the susceptibility to mass movements of individual lithological units, a displacement lithological index was calculated, defined for the purposes of this study as the ratio of the volume of surface deformation in landslides in a given lithological unit to the surface of a given lithological unit according to the formula:

$$
W_{p}=\frac{V_{p}}{P}\left[\frac{\mathrm{m}^{3}}{\mathrm{~m}^{2}}\right]
$$

where: $V_{p}$ - the sum of the volume of surface deformation within the landslides in a given lithological unit (both depression and uplift); $P$ the surface of a given lithological unit covered by the ALS data, excluding the anthropogenically transformed sites and the lake area. 


\section{LIST OF PASSIVE FACTORS}

The source of data on passive factors was the DTM, Detailed Geological Maps of Poland 1:50,000 (SMGP) (Cieszkowski et al., 1987; Burtan et al., 1991), Database of General Geographical Objects (BDOO) from the Polish Geodetic and Cartographic Resource and my own field observations. Data were compiled in a GIS in the form of thematic layers, characterized by common georeferencing (Polish Geodetic System 1992)

For the purposes of the research, a map of lithological units was made, including tectonic dislocations. For this purpose, all overthrusts and faults determined on the SMGP maps as well as dislocations marked and interpreted during DTM analyses were used. Then, a map of the distance to faults and overthrusts shown in specific intervals was created, limiting the distance of impact on the activity of landslides to $500 \mathrm{~m}$ and a map of the occurrence of boundaries of lithological units with a 100-metre-buffer.

With the use of Global Mapper 21 and Ilwis 3.4 software, based on the DTMs, morphometric features of the slopes were determined and maps of slopes, slope exposures and of absolute altitude were prepared. The continuous data obtained were classified into appropriate ranges. The next layer for the calculations, based on the DTM, was the watercourse distance map. The last compiled layer was the land cover map, which was prepared on the basis of the BDOO.

\section{CALCULATIONS OF LANDSLIDE SUSCEPTIBILITY}

Landslide susceptibility is the possibility of a landslide occurring in a given area due to the environmental conditions existing there (Brabb, 1984; Varnes, 1984). Extensive reviews of the methods used to assess landslide susceptibility are provided by van Westen et al. (1999), Carrara et al. (1999) and van Westen et al. (2008). In determining vulnerability, an accurate inventory of landslides along with the determination of their extent is important (Glade and Crozier, 2005; Galli et al., 2008). Comparing maps of passive factors and landslide maps allows for a statistical determination of the importance of a given factor in the development of mass movements.

To calculate the landslide susceptibility of the slopes in the Rożnów Lake area, it was decided to use the Weight of Evidence method (WoE), which has been successfully used for other regions of the Carpathians, e.g. for the Szymbark region (Mrozek, 2013), in the Sudetes (Sikora and Wojciechowski, 2019) as well as for the urban areas of the Polish coast (Małka, 2021) and for the whole of Poland (Wojciechowski, 2019). This method is also used worldwide (Van Westen et al., 2003; Lee and Choi, 2004; Pradhan et al., 2010a; Liu and Duan, 2018). The statistical two-dimensional WoE method is based on Bayes probabilities (Bonham-Carter et al., 1989; Bonham-Carter, 1994). Significant indicators in the calculations are the ratio of the landslide area to the area of the entire study area and the ratio of the landslide area to the area of a given class of the passive factor. I/wis 3.4 software was used to calculate the susceptibility.

Thanks to earlier DDM analyses, it was possible to use for calculations only those landslides that were active in the period between 2010 and 2019, which increased the reliability of the results.

\section{RESULTS OF ANALYSIS OF DIFFERENTIAL DIGITAL TERRAIN MODELS AND INTERPRETATION}

\section{LANDSLIDES ON DDM FROM 2010-2011/2013}

After the "landslide catastrophe", $>62 \%$ of all currently recorded landslides became active in the south-eastern part of the research area. Landslides with the largest displacements lie in the belt between Znamirowice, Gródek nad Dunajcem and Przydonica (Fig. 5). The geological structure of the substrate is dominated by thin-bedded flysch of the Silesian unit - mainly the Hieroglyphic Beds, Variegated Shales and Menilite Shales (Fig. 2). The Przydonica overthrust is also present in this area. Along this local structure, in 2010, numerous landslides were activated (Wódka, 2020), including in Przydonica (Figs. 6 and 7).

The second area with large areas where the displacements took place is marked in the area of Zbyszyce. It is an area located in the overthrust zone of three units - the Grybów Nappe, Silesian Nappe and Magura Nappe (Burtan and SkoczylasCiszewska, 1964; Burtan et al., 1991). Large parts of landslides became active in highly tectonized zones within the Inoceramus and Variegated Shales of the Magura Nappe, as well as medium and thin-bedded sandstones and shales of the Krosno Beds of the Grybów Nappe.

Based on the DDM analyses, it was found that out of 256 landslides occurring in the area coinciding with the 2010 flights, 159 were activated. The greatest vertical displacements resulting from the activation of these landslides reached $9 \mathrm{~m}$ for the ground depressions and $7.5 \mathrm{~m}$ for the elevations in the area. Among the landslides activated in the period 2010-2013, most recorded displacements were in the range of $-1 \mathrm{~m}$ to $+1 \mathrm{~m}$. These displacements on the DDM covered nearly $6.6 \mathrm{~km}^{2}$ of the land surface, which constitutes $98 \%$ of all registered displacements. A significant area was also covered by displacements in the range -3 to -1 and +1 to $+3 \mathrm{~m}$.

Significant changes in the boundaries of landslides after the heavy rains of 2010 were recorded in $5.5 \%$ of cases, of which new landslide forms were found only in $1.6 \%$ of cases. Most of these are located in highly tectonized zones (faults, overthusts). These landslides developed both in the thin flysch deposits and in the thick-bedded sandstones.

Out of 19 landslides which increased their areas after 2010, 5 developed in the thick-bedded sandstones and shales of the Krosno Beds, 5 within the Ciężkowice sandstone outcrops, 3 within the Hieroglyphic shales, 2 within the thin-bedded sandstones and the shales of the Krosno Beds, one within the shale of the Krosno Beds, one within the Menilite shale and one in the surface dposits, namely loess. At least 8 of these landslides developed in fault zones, and 2 in an overthrust zone.

The Differential Digital Terrain Model made it possible to calculate the volume of soils (i.e. rock masses) that were lowered or uplifted in individual lithological units and to determine the displacement index $(\mathrm{Wp})$ for individual lithological units. The value of Wp for individual units is shown in Table 1.

In the period 2010-2011/2013, the surface displacements in the study area encompassed $903,811 \mathrm{~m}^{3}$ of soil and rocks. The results of the calculations indicated that the highest displacement coefficient occurred in the thin-bedded flysch depos- 


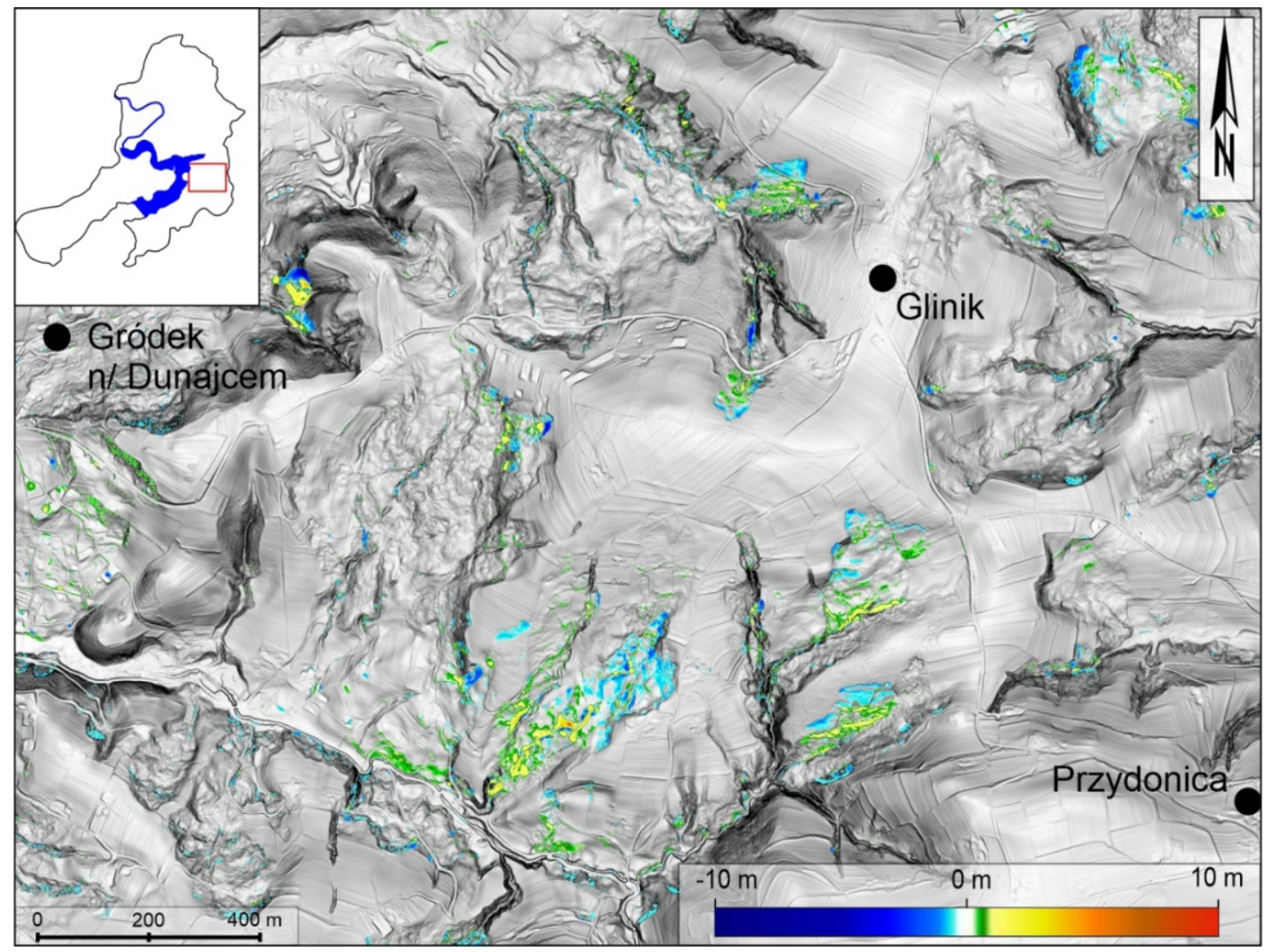

Fig. 5. DDM (2011-2010) of part of the research area between Gródek nad Dunajcem and Przydonica

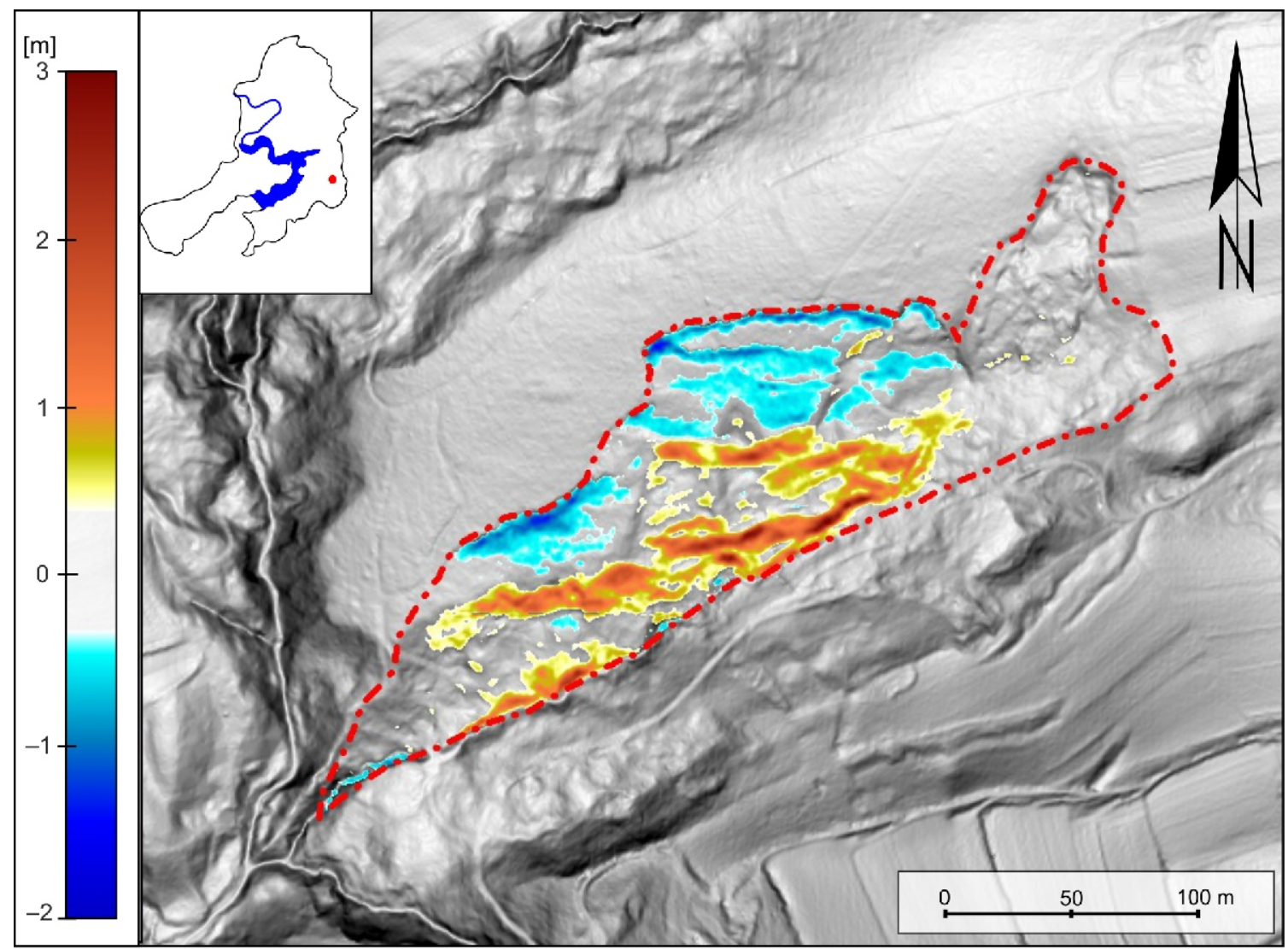

Fig. 6. Differential model of the translational landslide in Przydonica 


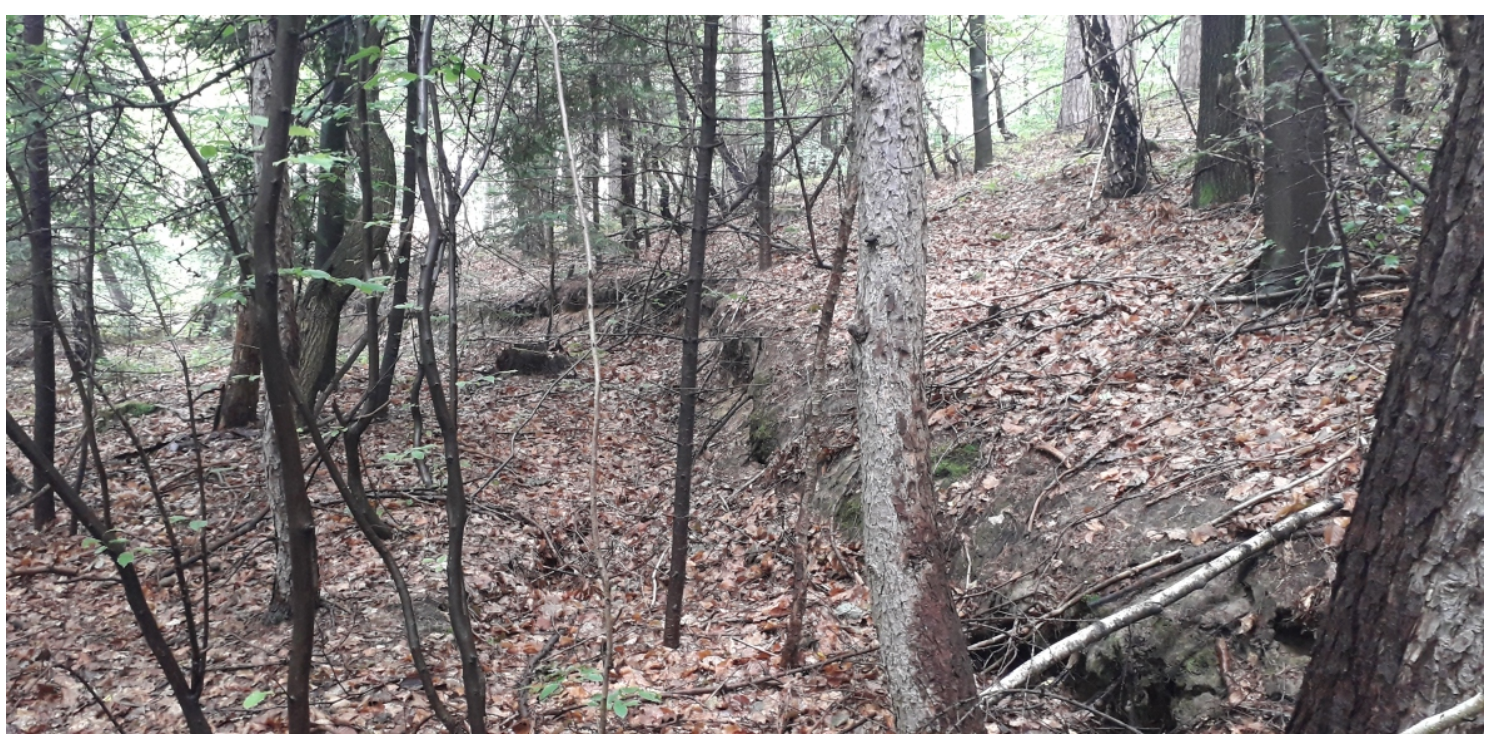

Fig. 7. A part of the rectilinear main scarp of the landslide in Przydonica, formed after 2010

The volume of surface deformation for individual lithological units in 2010-2011/2013

\begin{tabular}{|c|c|c|c|c|c|}
\hline Ranking & Lithological unit & $\begin{array}{l}\text { Uplift volume } \\
{\left[\mathrm{m}^{3}\right]}\end{array}$ & $\begin{array}{l}\text { Decrease volume } \\
{\left[\mathrm{m}^{3}\right]}\end{array}$ & $\begin{array}{c}\text { Sum of the volumes of } \\
\text { surface deformation } \\
{\left[\mathrm{m}^{3}\right]}\end{array}$ & $\begin{array}{c}\text { Displacement index } \\
{\left[\mathrm{m}^{3} / \mathrm{m}^{2}\right]}\end{array}$ \\
\hline 1 & $\begin{array}{l}\text { sandstones and shales - } \\
\text { Hieroglyphic Beds (S) }\end{array}$ & 155,234 & 164,205 & 319,439 & 0.072 \\
\hline 2 & upper Istebna shales (S) & 7,498 & 8,013 & 15,512 & 0.057 \\
\hline 3 & Ciężkowice sandstones (S) & 60,885 & 85,204 & 146,090 & 0.055 \\
\hline 4 & $\begin{array}{l}\text { sandstones and shales - } \\
\text { Inoceramus Beds (M) }\end{array}$ & 44,110 & 39,964 & 39,964 & 0.048 \\
\hline 5 & $\begin{array}{c}\text { shales, sandstones, cherts - } \\
\text { Menillite Beds (S) }\end{array}$ & 22,067 & 16,413 & 38,480 & 0.046 \\
\hline 6 & $\begin{array}{c}\text { sandstones and shales - } \\
\text { Krosno Beds }(G)\end{array}$ & 47,604 & 50,903 & 98,507 & 0.042 \\
\hline 7 & variegated shales $(\mathrm{S})$ & 13,636 & 7,820 & 21,458 & 0.034 \\
\hline 8 & variegated shales $(\mathrm{M})$ & 4,748 & 8,186 & 12,934 & 0.025 \\
\hline 9 & upper Istebna sandstones (S) & 2,677 & 3,211 & 5,888 & 0.017 \\
\hline 9 & $\begin{array}{c}\text { sandstones and shales - } \\
\text { Krosno Beds (S) }\end{array}$ & 100,450 & 48,600 & 149,050 & 0.017 \\
\hline 11 & $\begin{array}{l}\text { shales, cherts, sandstones - } \\
\text { Grybów Beds (G) }\end{array}$ & 1,560 & 1,085 & 2,645 & 0.013 \\
\hline 12 & $\begin{array}{c}\text { shales and sandstones - } \\
\text { Krosno Beds (S) }\end{array}$ & 2,334 & 7,321 & 9,655 & 0.009 \\
\hline 13 & Cergowa sandstones (G) & 55 & 24 & 79 & $<0.001$ \\
\hline
\end{tabular}

*M - Magura Nappe; S - Silesian Nappe; G - Grybów Nappe

its, mainly shale-sandstone. Of note is the high index of the thick-bedded Ciężkowice sandstones, which due to their massive nature are generally associated with low landslide susceptibility. Additionally, it was in the Ciężkowice sandstones that the greatest amount of landslide deformation, reaching $-7 \mathrm{~m}$, were recorded (Fig. 8). The reason for this may lie in the geological conditions, to explain the high landslide susceptibility of the Ciężkowice sandstones. Medium and coarse-grained sandstones with lenses of conglomerate are relatively porous and permeable. The factor here may be both the larger grain size and the less compact structure of the rock compared to, for example, the Magura sandstones. Additionally, in the area of Lake
Rożnów, the Ciężkowice sandstones form two levels between the variegated shales (Fig. 9). The loading of the sandstones by the infiltrating water causes the launch of the chutes developed on the variegated shales underlying them, which, due to the massive structure of the sandstones, leads to large-scale deformation.

The results of DDM analyses were compared with field assessment of the landslide activity. This was possible because, in the period between the flights, for part of the research area, field mapping of landslides was performed. The agreement of the field activity assessment with the results of DMT analyses was estimated at $67 \%$. This indicates a high degree of subjec- 


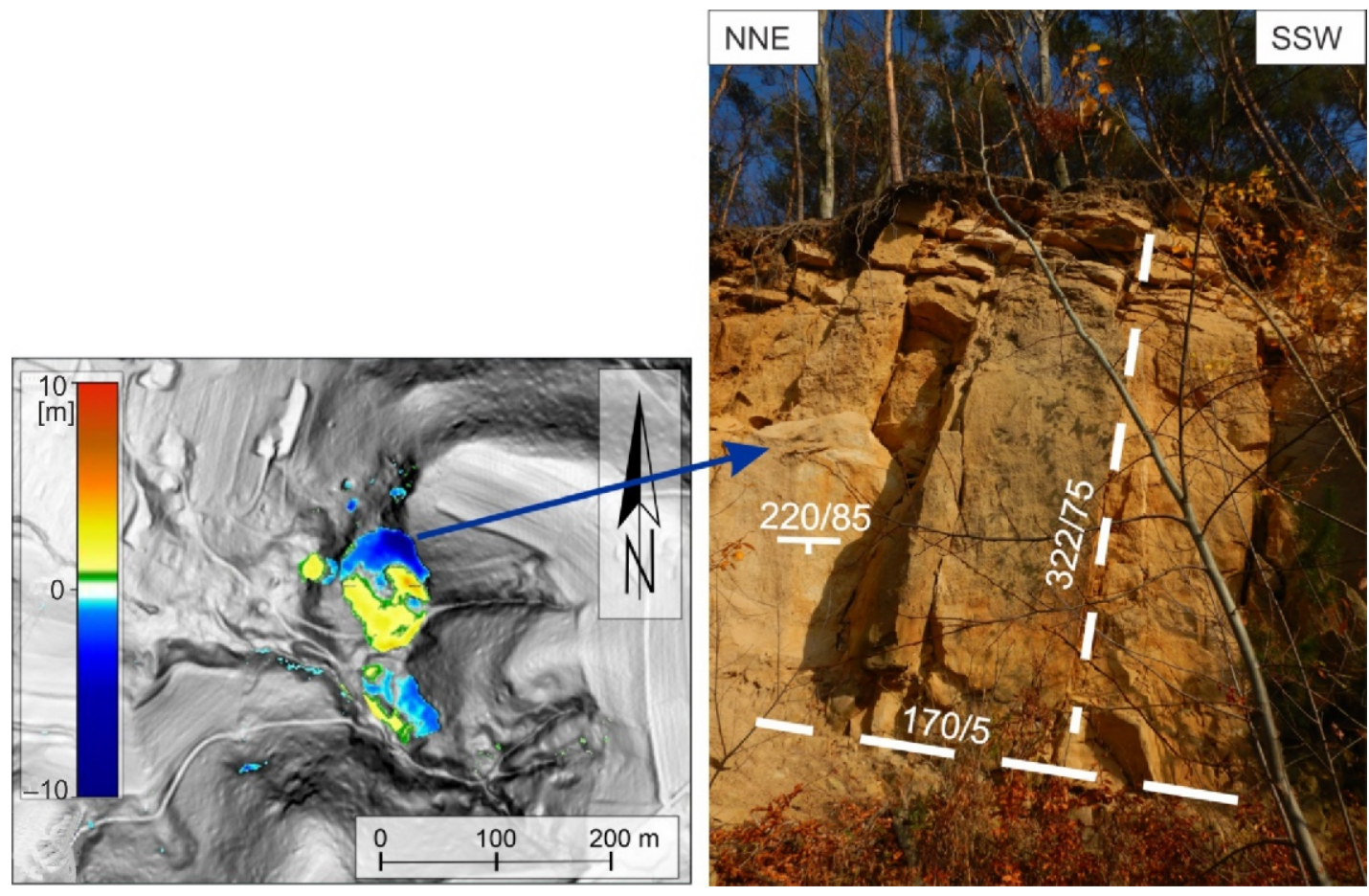

Fig. 8. The largest decrease recorded on a DDM resulting from the formation of a landslide slope in the Ciężkowice sandstones

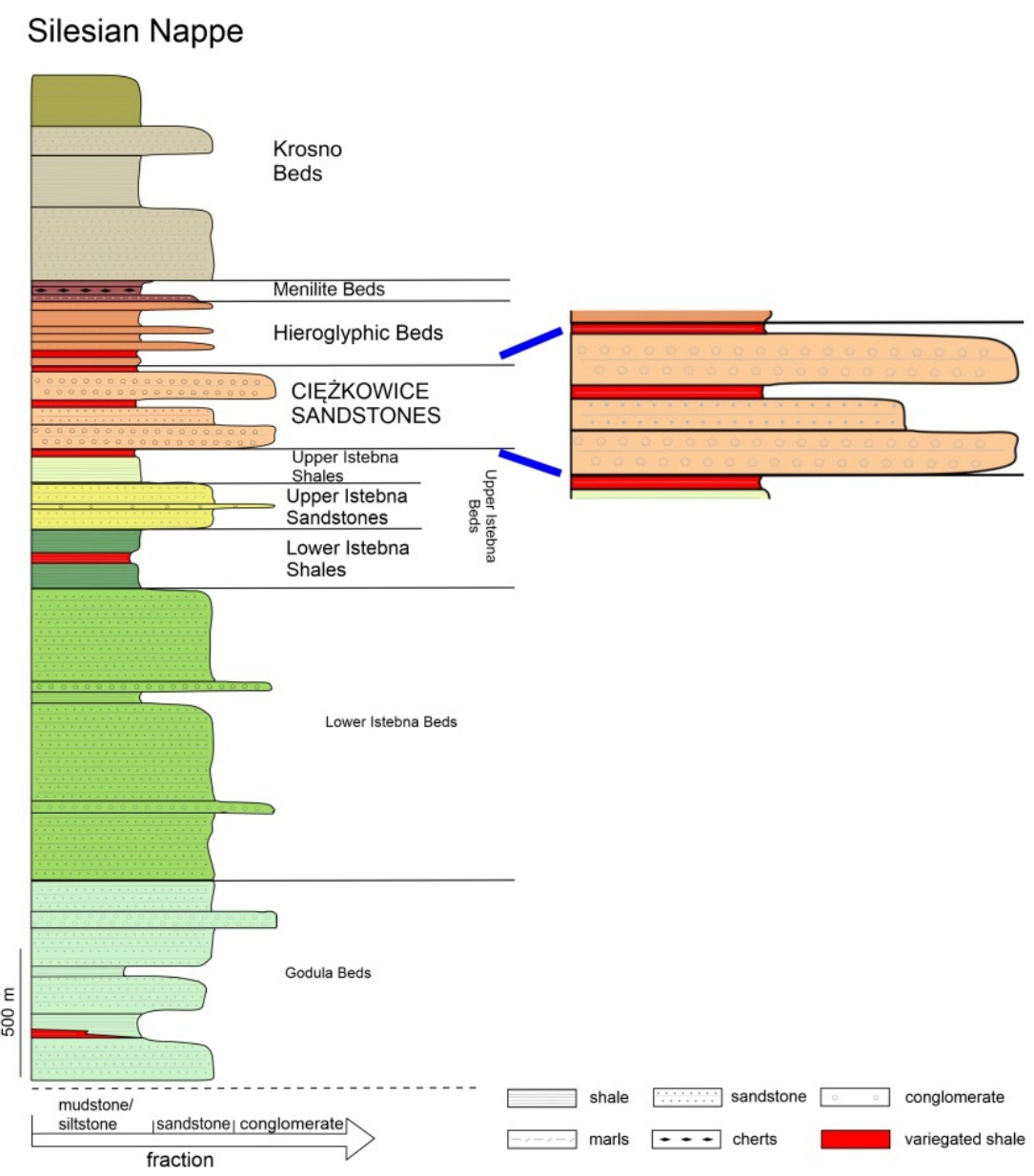

Fig. 9. Generalized lithological profile of the Silesian Nappe deposits in the research area (based on Burtan and Skoczylas-Ciszewska, 1964; Burtan et al., 1991; Cieszkowski, 1992a, b; Leszczyński et al., 1994; Paul, 1997) 
tivism in the field of activity assessment. On the other hand, in a few cases landslide activity was found in the field based on the presence of small fractures in the ground that were not visible on the DDM, indicating drawbacks of the differential models.

\section{LANDSLIDES ON DDM 2011/2013-2018}

Other ALS flights, covering a large part of the research area, were made in 2018 (Fig. 4). The model obtained was compared with the DTM made as part of the ISOK project (data from 2011 for the northern part of the research area and from 2013 for the southern part).

In total, 1,006 landslide forms were included in the scope of ALS in 2018. On the basis of the differential model, activations were found in 128 of them (Fig. 10). Thus, in the period between measurements, $\sim 13 \%$ of landslides were active. As a rule, these were displacements covering small (up to $3 \%$ ) parts of the landslides. In a few cases, larger areas were activated, covering a maximum of $45 \%$ of the landslide surface. In the period 2011-2018, significantly lower displacement values were observed than immediately after the "landslide disaster". The maximum uplift of the area was $5.5 \mathrm{~m}$ with depressions of $3 \mathrm{~m}$. Analyses of the DDM did not reveal the formation of new land- slides. Activations occurred within the old landslide forms. Only in 5 cases was there a slight increase in landslide area (Fig. 11).

Most of the activated landslides developed in the thin-bedded flysch formations, and more than half of them are located in zones of tectonic dislocation. A significant number of the landslides occurs in the area of Gródek nad Dunajcem, within the outcrops of the Hieroglyphic Beds of the Silesian Nappe (Fig. 10) and in the area of Zbyszyce, within the Inoceramus Beds of the Magura Nappe (Fig. 10). A large proportion of the activated landslides is also located within the outcrops of the lower Istebna Beds, represented by thick-bedded sandstones and conglomerates; however, in these landslides, only slight displacements occurred, usually involving surface loess-like and weathered deposits.

In some cases, although usually in landslides covering small areas, the terrain was completely leveled and the landslide relief was obliterated, making it impossible to efficiently identify the landslide and to delineate its boundaries. Such complete blurring of the landslide relief can be observed on the DTM from the area of Bilsko (Fig. 12A) and Rąbkowo (Fig. 12B). Inaccurate interpretation of the DDM in these cases could lead to erroneous assessment of these landslides as active.

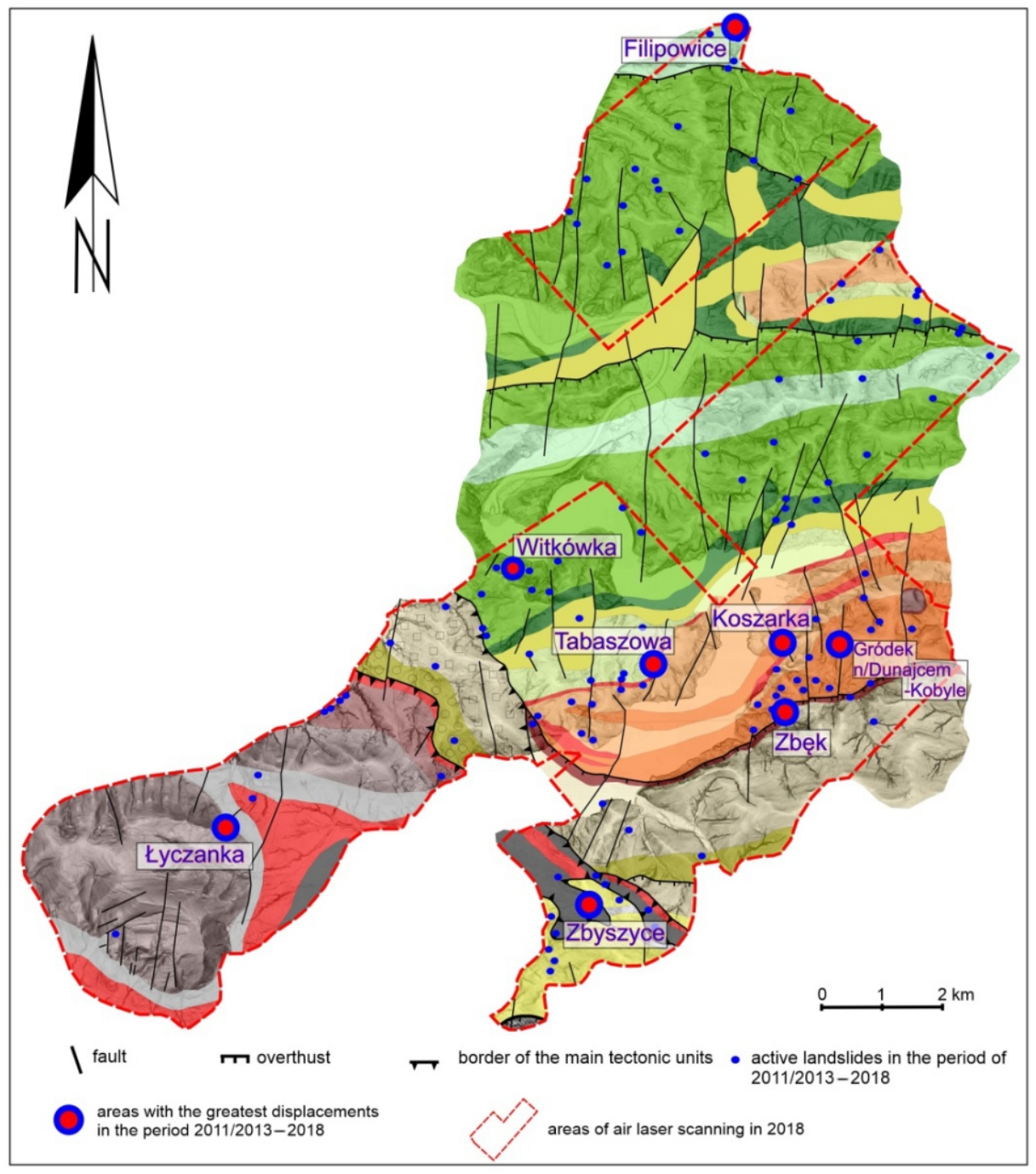

Fig. 10. Location of landslides activated in the period 2011-2018 against the background of the geological map 


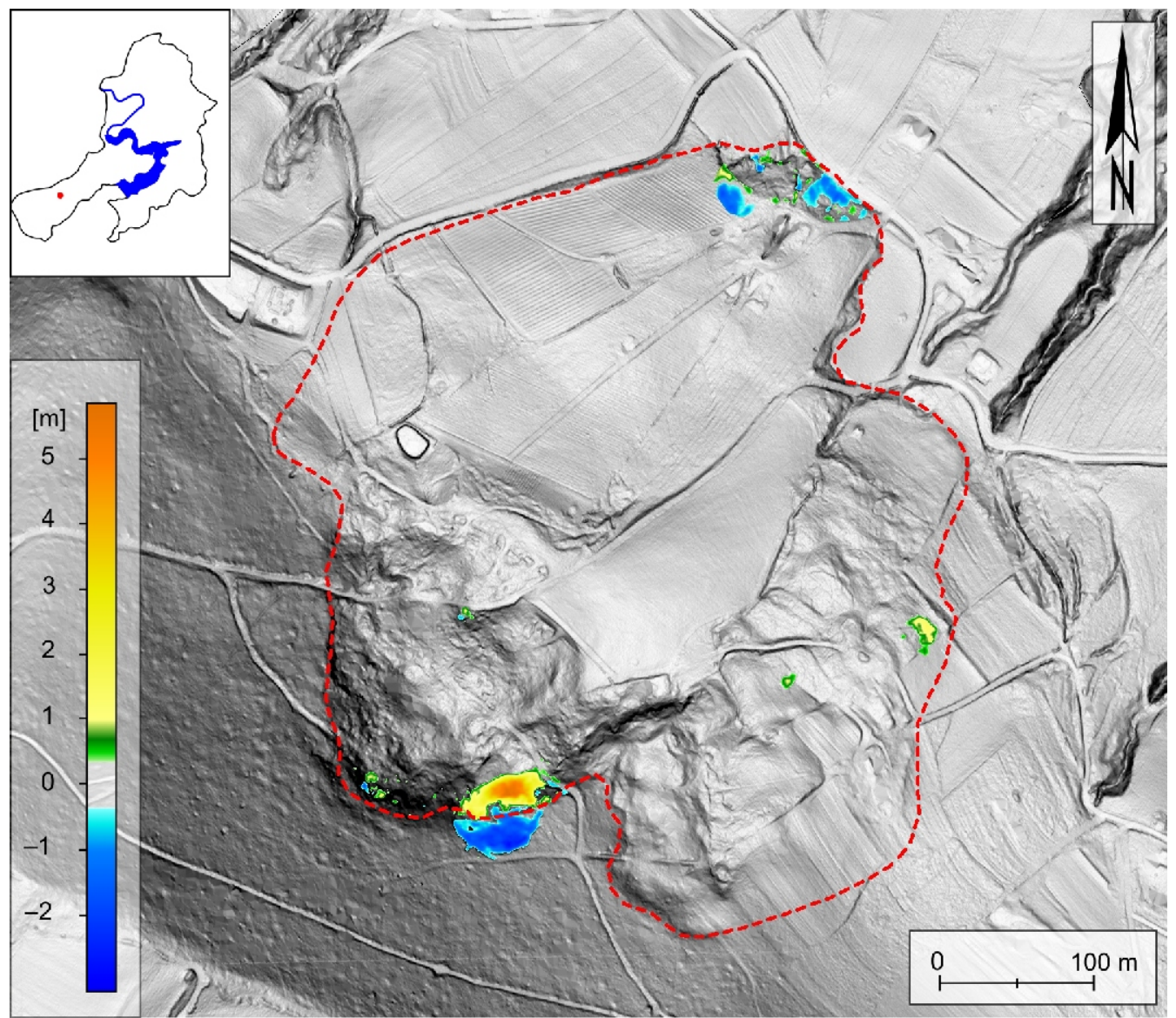

Fig. 11. DDM (2018-2013) of the landslide in Łyczanka (the red dashed line indicates the extent of the landslide in 2013)

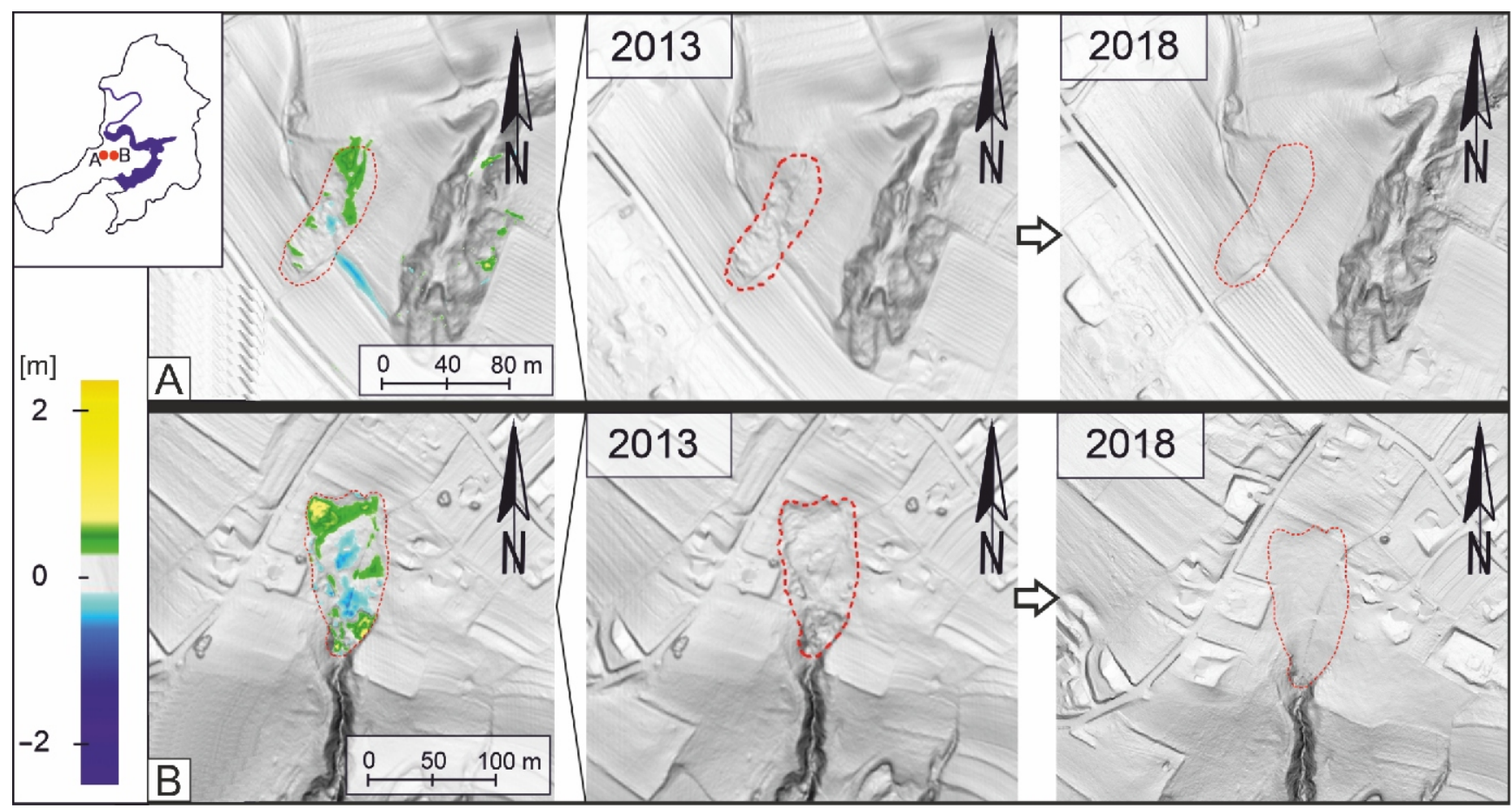

Fig. 12. Differential Digital Terrain Model of landslides in Bilsko (A) and Rąbkowa (B) resulting from anthropogenic blurring of the landslide relief in the period 2013-2018 
In the period between $2011 / 2013$ and 2018, 1,058,460 $\mathrm{m}^{3}$ of soil and rock were displaced over an area of $\sim 93 \mathrm{~km}^{2}$. As in the previous years, the highest displacement rates were observed within the thin-bedded flysch, mainly of shale and sandstone (Table 2). The Hieroglyphic Beds were in the highest position, within which the surface deformation, despite the eight-fold longer duration, was less than half the amount seen after the 2010 landslide disaster. The Ciężkowice Sandstones is the much lower position in the ranking. The reason for this may be the lack of long-term rainfall to sufficiently load and reduce the stability of the slopes built of these deposits. During this period, the Ciężkowice Sandstones, like other thick-bedded formations, were characterized by a much lower displacement index.

\section{LANDSLIDES ON DDM FROM 2018 TO 2019}

The analyses showed displacements within 39 landslides (Fig. 13), i.e. $<4 \%$ of the forms that were covered by the flights. These were usually small displacements, usually ranging from -0.6 to $0.6 \mathrm{~m}$, and included small parts of the landslide area (from 1 to 10\%; Fig. 14). In the period 2018-2019, no new landslides were recorded. By contrast with the DTM analyses from previous years, no significant changes in the extent of previously existing landslides were observed.

The distribution of the activated landslides is irregular and scattered throughout the study area (Fig. 13), but most of them developed within the thin-bedded flysch: Hieroglyphic Beds of the Silesian and Magura Nappes, Inoceramus Beds of the Magura Nappe, variegated shales of the Silesian Nappe and upper or lower shales of the Istebna Beds of the Silesian Nappe. Several landslides became active on the sandstone and shale outcrops of the lower Istebna Beds. Twenty-five of the activated landslides are located in tectonic dislocation zones.

The displacement index for individual lithological units in the period 2018-2019 is shown in Table 3.

DDM analyses from 2010-2019 showed a total of 246 landslide activations, of which 55 were activated at least twice (Fig. 15). During this period, 23 landslide forms were found in the study area which developed on slopes previously not affected by mass movements or covered such slopes as a result of increasing their area (Fig. 15). New landslides were found only after the 2010 "landslide catastrophe".

The results of the analysis of DDMs in the area of Rożnów Lake indicate that in the period 2010-2019 most landslides were

$\mathrm{T}$ a b le 2

The volume of surface deformation for individual lithological units in 2011/2013-2018

\begin{tabular}{|c|c|c|c|c|c|}
\hline Ranking & Lithological unit & $\begin{array}{l}\text { Uplift volume } \\
{\left[\mathrm{m}^{3}\right]}\end{array}$ & $\begin{array}{c}\text { Decrease volume } \\
{\left[\mathrm{m}^{3}\right]}\end{array}$ & $\begin{array}{c}\text { Sum of the volumes of } \\
\text { surface deformations } \\
{\left[\mathrm{m}^{3}\right]}\end{array}$ & $\begin{array}{l}\text { Displacement index } \\
{\left[\mathrm{m}^{3} / \mathrm{m}^{2}\right]}\end{array}$ \\
\hline 1 & $\begin{array}{c}\text { sandstones and shales - } \\
\text { Hieroglyphic Beds (S) }\end{array}$ & 75,351 & 76,060 & 151,411 & 0.036 \\
\hline 2 & upper Istebna shales (S) & 43,119 & 40,293 & 83,412 & 0.031 \\
\hline 3 & variegated shales $(\mathrm{S})$ & 9,070 & 8,448 & 17,518 & 0.026 \\
\hline 4 & $\begin{array}{c}\text { shales, sandstones, cherts - } \\
\text { Menillite Beds (S) }\end{array}$ & 10,530 & 9,139 & 19,669 & 0.025 \\
\hline 5 & $\begin{array}{l}\text { sandstones and shales - } \\
\text { Inoceramus Beds (M) }\end{array}$ & 12,654 & 11,025 & 23,679 & 0.02 \\
\hline 5 & $\begin{array}{l}\text { shales and sandstones - } \\
\text { Hieroglyphic Beds (M) }\end{array}$ & 17,071 & 21,337 & 38,408 & 0.2 \\
\hline 5 & $\begin{array}{l}\text { shales, marls, sandstones - } \\
\text { Zembrzyce Beds (M) }\end{array}$ & 9,305 & 15,571 & 24,876 & 0.2 \\
\hline 5 & $\begin{array}{c}\text { sandstones and shales - } \\
\text { Krosno Beds }(G)\end{array}$ & 17,600 & 17,066 & 34,666 & 0.2 \\
\hline 9 & Ciężkowice sandstones (S) & 25,324 & 36,422 & 61,746 & 0.019 \\
\hline 10 & $\begin{array}{c}\text { sandstones and shales - } \\
\text { Godula Beds (S) }\end{array}$ & 37,484 & 39,916 & 77,401 & 0.018 \\
\hline 11 & $\begin{array}{c}\text { sandstones and conglomerates - } \\
\text { Lower Istebna Beds (S) }\end{array}$ & 104,869 & 176,581 & 281,450 & 0.015 \\
\hline 12 & $\begin{array}{l}\text { lower Istebna shales - } \\
\text { Upper Istebna Beds (S) }\end{array}$ & 33,205 & 33,949 & 67,154 & 0.014 \\
\hline 13 & upper Istebna sandstones (S) & 23,571 & 25,285 & 48,856 & 0.010 \\
\hline 13 & $\begin{array}{l}\text { sandstones and shales - } \\
\text { Cergowa Beds (Mi) }\end{array}$ & 17,004 & 14,768 & 31,772 & 0.010 \\
\hline 13 & Cergowa sandstones $(\mathrm{G})$ & 515 & 546 & 1,061 & 0.010 \\
\hline 16 & $\begin{array}{l}\text { shales, cherts, sandstones - } \\
\text { Grybów Beds (G) }\end{array}$ & 557 & 506 & 1,063 & 0.005 \\
\hline 17 & $\begin{array}{c}\text { Sandstones and shales - } \\
\text { Krosno Beds (S) }\end{array}$ & 14,398 & 12,608 & 27,006 & 0.004 \\
\hline 17 & variegated shales $(\mathrm{M})$ & 5,391 & 7,251 & 12,642 & 0.004 \\
\hline 19 & Magura sandstones (M) & 22,909 & 12,980 & 35,889 & 0.003 \\
\hline 20 & shales - Cergowa Beds (Mi) & 5,299 & 2,338 & 7,637 & 0.002 \\
\hline 21 & $\begin{array}{c}\text { shales and sandstones - } \\
\text { Krosno Beds (S) }\end{array}$ & 1,884 & 2,690 & 4,574 & $<0.001$ \\
\hline
\end{tabular}




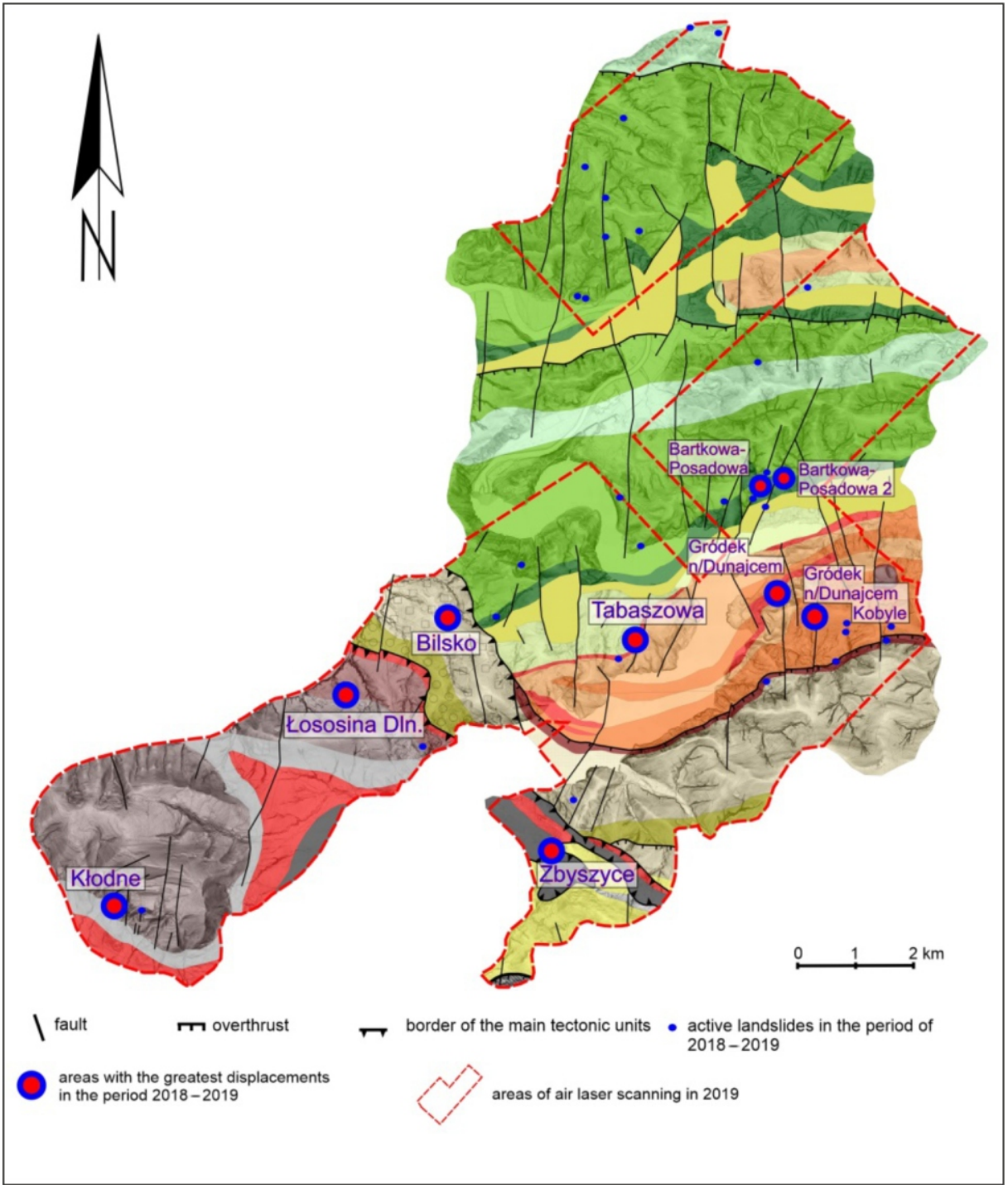

Fig 13. Location of landslides with the largest surface changes as a result of mass movements in 2018-2019 shown on the geological map

Colour of lithological units as in Figure 2
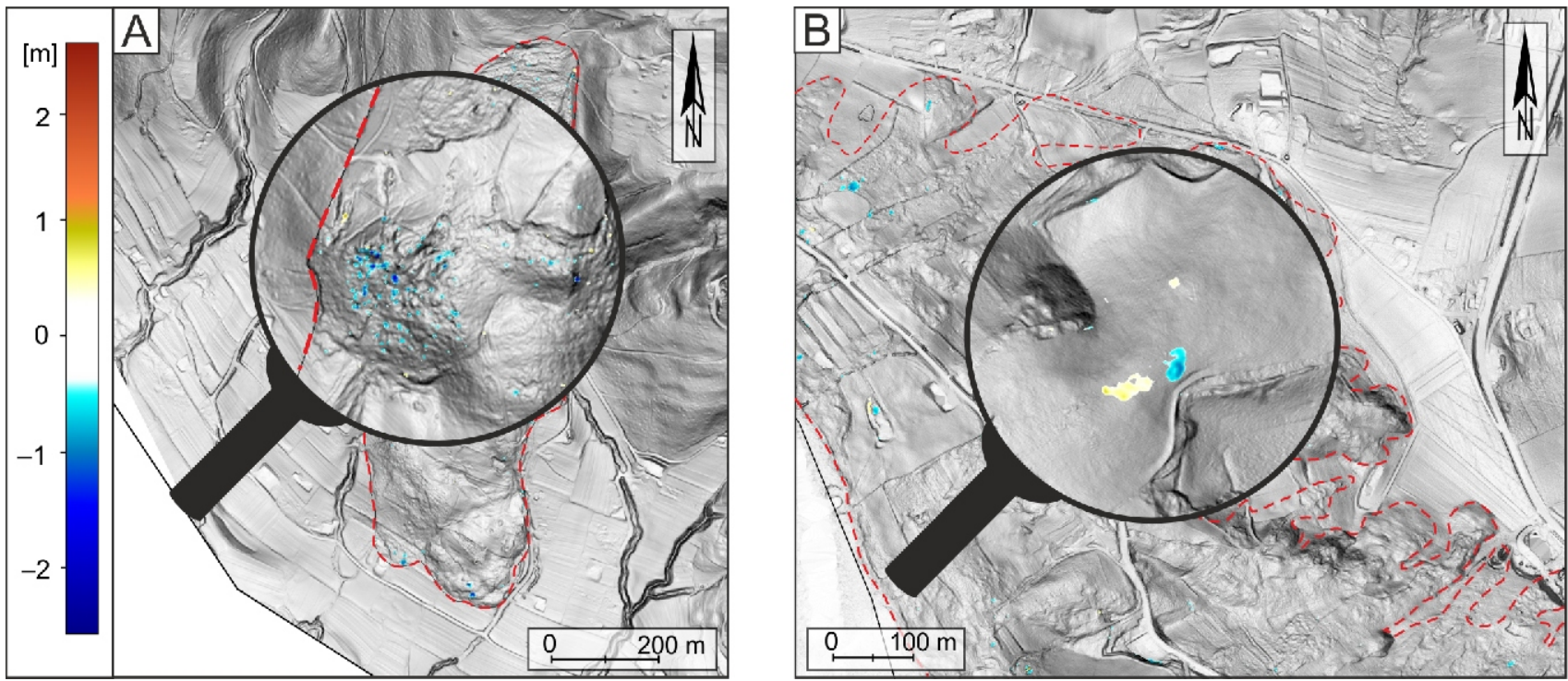

Fig. 14. DDM of landslides where the largest displacements were recorded in 2018-2019

A - landslide in Kłodno; B - landslide in Zbyszyce 
The volume of surface deformation for individual lithological units in 2018-2019

\begin{tabular}{|c|c|c|c|c|c|}
\hline Ranking & Lithological unit & $\begin{array}{l}\text { Uplift volume } \\
\qquad\left[\mathrm{m}^{3}\right]\end{array}$ & $\begin{array}{l}\text { Decrease volume } \\
{\left[\mathrm{m}^{3}\right]}\end{array}$ & $\begin{array}{c}\text { Sum of the volumes of } \\
\text { surface deformations } \\
{\left[\mathrm{m}^{3}\right]}\end{array}$ & $\begin{array}{l}\text { Displacement index } \\
\qquad\left[\mathrm{m}^{3} / \mathrm{m}^{2}\right]\end{array}$ \\
\hline 1 & $\begin{array}{l}\text { sandstones and shales - } \\
\text { Hieroglyphic Beds (S) }\end{array}$ & 26,764 & 34,940 & 61,704 & 0.015 \\
\hline 2 & $\begin{array}{l}\text { sandstones and shales - } \\
\text { Inoceramus Beds (M) }\end{array}$ & 5,616 & 21,857 & 27,473 & 0.014 \\
\hline 3 & upper Istebna shales (S) & 16,614 & 17,960 & 34,574 & 0.013 \\
\hline 3 & $\begin{array}{c}\text { shales, marls, sandstones - } \\
\text { Zembrzyce Beds (M) }\end{array}$ & 4,420 & 15,587 & 20,008 & 0.013 \\
\hline 5 & variegated shales (S) & 3,178 & 4,229 & 7,407 & 0.012 \\
\hline 6 & $\begin{array}{l}\text { lower Istebna shales - } \\
\text { Upper Istebna Beds (S) }\end{array}$ & 16,384 & 15,774 & 32,158 & 0.01 \\
\hline 6 & $\begin{array}{l}\text { sandstones and shales - } \\
\text { Krosno Beds }(G)\end{array}$ & 3,336 & 17,860 & 21,196 & 0.01 \\
\hline 8 & Ciężkowice sandstones (S) & 15,747 & 20,796 & 36,543 & 0.009 \\
\hline 8 & $\begin{array}{l}\text { shales, cherts, sandstones - } \\
\text { Grybów Beds }(G)\end{array}$ & 99 & 1,743 & 1,842 & 0.009 \\
\hline 10 & shales - Cergowa Beds (Mi) & 2,499 & 8,145 & 10,644 & 0.008 \\
\hline 10 & $\begin{array}{l}\text { shales and sandstones - } \\
\text { Hieroglyphic Beds (M) }\end{array}$ & 6,860 & 12,961 & 19,821 & 0.008 \\
\hline 12 & Cergowa sandstones (G) & 364 & 354 & 718 & 0.007 \\
\hline 13 & $\begin{array}{c}\text { sandstones and conglomerates - } \\
\text { Lower Istebna Beds (S) }\end{array}$ & 74,236 & 67,605 & 141,841 & 0.006 \\
\hline 14 & upper Istebna sandstones (S) & 7,359 & 8,709 & 16,068 & 0.005 \\
\hline 14 & $\begin{array}{c}\text { sandstones and shales - } \\
\text { Cergowa Beds (Mi) }\end{array}$ & 6,041 & 10,597 & 16,639 & 0.005 \\
\hline 16 & $\begin{array}{c}\text { sandstones and shales - } \\
\text { Krosno Beds (S) }\end{array}$ & 5,990 & 14,745 & 20,735 & 0.003 \\
\hline 16 & $\begin{array}{c}\text { shales and sandstones - } \\
\text { Krosno Beds (S) }\end{array}$ & 551 & 2,327 & 2,879 & 0.003 \\
\hline 16 & variegated shales $(\mathrm{M})$ & 2,288 & 8,684 & 10,972 & 0.003 \\
\hline 19 & Magura sandstones (M) & 5,781 & 13,066 & 18,847 & 0.002 \\
\hline 20 & $\begin{array}{l}\text { shales, sandstones, cherts - } \\
\text { Menillite Beds (S) }\end{array}$ & 2,358 & 3,291 & 5,649 & 0.001 \\
\hline 21 & $\begin{array}{c}\text { sandstones and shales - } \\
\text { Godula Beds (S) }\end{array}$ & 11,707 & 9,421 & 22,86 & $<0.001$ \\
\hline
\end{tabular}

Table sorted by the highest displacement rate; explanations as in Tables 1 and 2

Table 4

Development of landslides in the area of Rożnów Lake in 2010-2019

\begin{tabular}{|c|c|c|c|}
\hline & $2010-2011 / 2013$ & 2011/2013-2018 & $2018-2019$ \\
\hline The number of landslides for which the DDM was made & 256 & 1006 & 1006 \\
\hline $\begin{array}{l}\text { Proportion of landslides within which activation was } \\
\text { found }\end{array}$ & $62.6 \%$ & $12.7 \%$ & $4.1 \%$ \\
\hline Proportion of landslides that widened the borders & $5.5 \%$ & $0.5 \%$ & $0 \%$ \\
\hline Proportion of newly formed landslides & $1.6 \%$ & $0 \%$ & $0 \%$ \\
\hline $\begin{array}{l}\text { Proportion of activated landslides located in tectonic } \\
\text { zones in relation to activated landslides (in relation to } \\
\text { all landslides) }\end{array}$ & $\begin{array}{c}65 \% \\
(40.6 \%)\end{array}$ & $\begin{array}{l}70.3 \% \\
(8.9 \%)\end{array}$ & $\begin{array}{l}73.8 \% \\
(3.1 \%)\end{array}$ \\
\hline $\begin{array}{l}\text { Sedimentary lithology, where the activation of land- } \\
\text { slides was the most frequent }\end{array}$ & $\begin{array}{l}\text { thin-bedded flysch } \\
\text { (61\% landslides) }\end{array}$ & $\begin{array}{l}\text { thin-bedded flysch } \\
\text { (58\% landslides) }\end{array}$ & $\begin{array}{l}\text { thin-bedded flysch } \\
\text { (55\% landslides) }\end{array}$ \\
\hline $\begin{array}{l}\text { Lithology of the deposits with the greatest displacement } \\
\text { and/or expansion of boundaries }\end{array}$ & thick-bedded sandstones & thin-bedded flysch & thin-bedded flysch \\
\hline Total volume of surface deformation within landslides & $\begin{array}{c}903,811 \mathrm{~m}^{3} \\
\text { (for the area } \sim 25 \mathrm{~km}^{2} \text { ) }\end{array}$ & $\begin{array}{c}1,058,460 \mathrm{~m}^{3} \\
\text { (for the area } \sim 93 \mathrm{~km}^{2} \text { ) }\end{array}$ & $\begin{array}{c}510,004 \mathrm{~m}^{3} \\
\text { (for the area } \sim 93 \mathrm{~km}^{2} \text { ) }\end{array}$ \\
\hline Lithological units with the highest displacement index & $\begin{array}{l}\text { Hieroglyphic Beds of the } \\
\text { Silesian Nappe }\end{array}$ & $\begin{array}{l}\text { Hieroglyphic Beds of } \\
\text { the Silesian Nappe }\end{array}$ & $\begin{array}{l}\text { Hieroglyphic Beds of } \\
\text { the Silesian Nappe }\end{array}$ \\
\hline
\end{tabular}




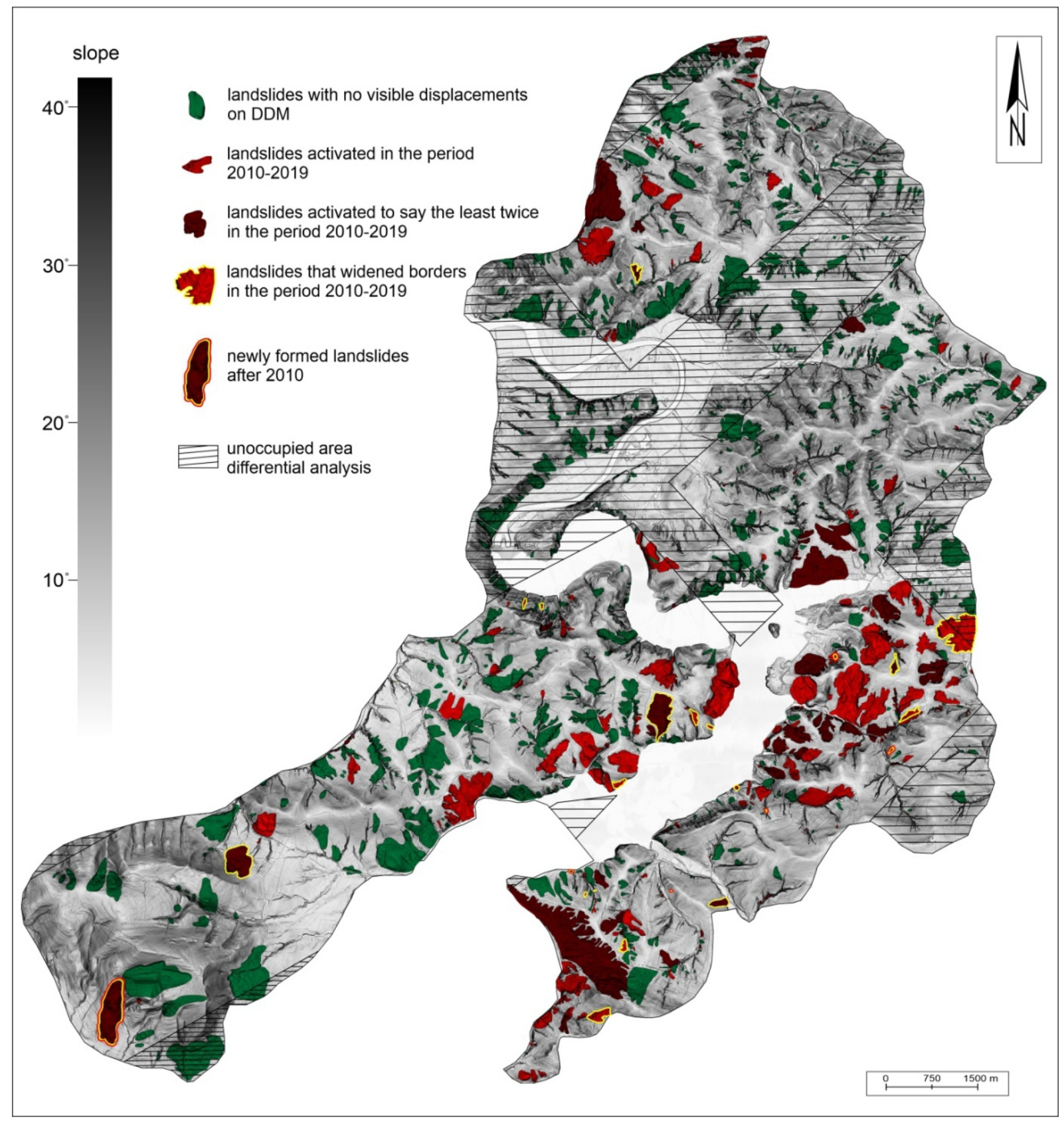

Fig. 15. Activity of landslides in the study area determined on the basis of DDM analyses

activated on slopes underlain by thin-bedded flysch deposits: sandstone-shale or shale-sandstone, which cover less than $25 \%$ of the study area. Regardless of the period, the most rejuvenated forms were recorded within the thin-bedded sandstones and shales of the Hieroglyphic Beds of the Silesian Nappe occurring in the area of Znamirowice, Gródek nad Dunajcem and Przydonica. Analysis of the repeatability of events also led to similar conclusions. Some 55 landslides, in the period 2010-2019, were activated at least twice. In 48 cases, mass movements developed within the thin-bedded formations, with the greatest number in the region noted above.

Most of the landslides in which the largest surface displacements occurred are located in zones of tectonic dislocations. In addition, there is an increase in the proportion of landslides activated in dislocation zones in less rainy periods (Table 4). The great majority of landslides, within which in the period
2010-2019 there were at least two activations, developed in zones where there are tectonic disturbances (faults, overthusts). Many of them are located in the area of the Przydonica overthrust and the overthrusting of the Magura Nappe onto the Silesian and Grybów nappes.

\section{SUSCEPTIBILITY OF SLOPES TO LANDSLIDES}

The analyses were based on prepared thematic layers taking into account the following factors: lithology, distance from the main tectonic dislocations (faults, overthrusts), land use, slope inclination, slope exposure, absolute height, distance from watercourses and the presence of lithological boundaries. The flat Dunajec valley and Rożnów Lake were excluded from the calculations. Statistical reasons for the activation of land- 
slides were calculated using only the areas of landslides that were considered active on the basis of DDMs in the period 2010-2019.

The results of statistical calculations clearly indicated that among the passive factors, lithology had the greatest impact on the activation of landslides in the last decade (Fig. 16 and Table 3). High values, reaching or exceeding 2, were obtained for the Hieroglyphic Beds of the Silesian Nappe, the Inoceramus Beds of the Magura Nappe, the Cergowa Beds of the Grybów Nappe and the Menilite Beds of the Silesian Nappe. These results are consistent with previous analyses, which indicated a large proportion of the these lithological units in the activation of landslides. The Hieroglyphic, Inoceramus and Menilite Beds were also characterized by high displacement indices calculated on the basis of DDMs (Tables 1-3). A high weight with values $>1$ was also obtained for the Krosno Beds of the Grybów Nappe, the Ciężkowice sandstones of the Silesian Nappe and the Cergowa shales of the Michalczowa Nappe (Table 5). According to calculations, slopes underlain by the Magura sandstones are the least susceptible to activation.
Another very important factor is the the presence of lithological boundaries (Table 5). This is seen in Figure 16, where the lithological contacts with the 100-metre-buffer used for the most part show dark-red and brown colours, and the remaining areas display negative values. High weighting values were calculated for the lithological contacts of the Silesian Nappe located in the belt between Znamirowice, Gródek nad Dunajcem and Przydonica. The lithological boundary of the variegated shale and the Ciężkowice sandstones is characterized by the highest value (Table 5). This contact promotes the development of mass movements due to differences in the permeability of the strata and the thickness of the sandstones, which when saturated, effectively add weight to the lower shales. Some lithological contacts have a negligible effect on the activation of landslides, and according to the statistics, some of them even hinder their development. The lowest calculated weighting is characteristic of the boundary between the Lower Istebna Beds and the Upper Istebna Beds (Table 5).

The values calculated indicate a significant influence of land use on the development of landslides. The highest value of 0.99

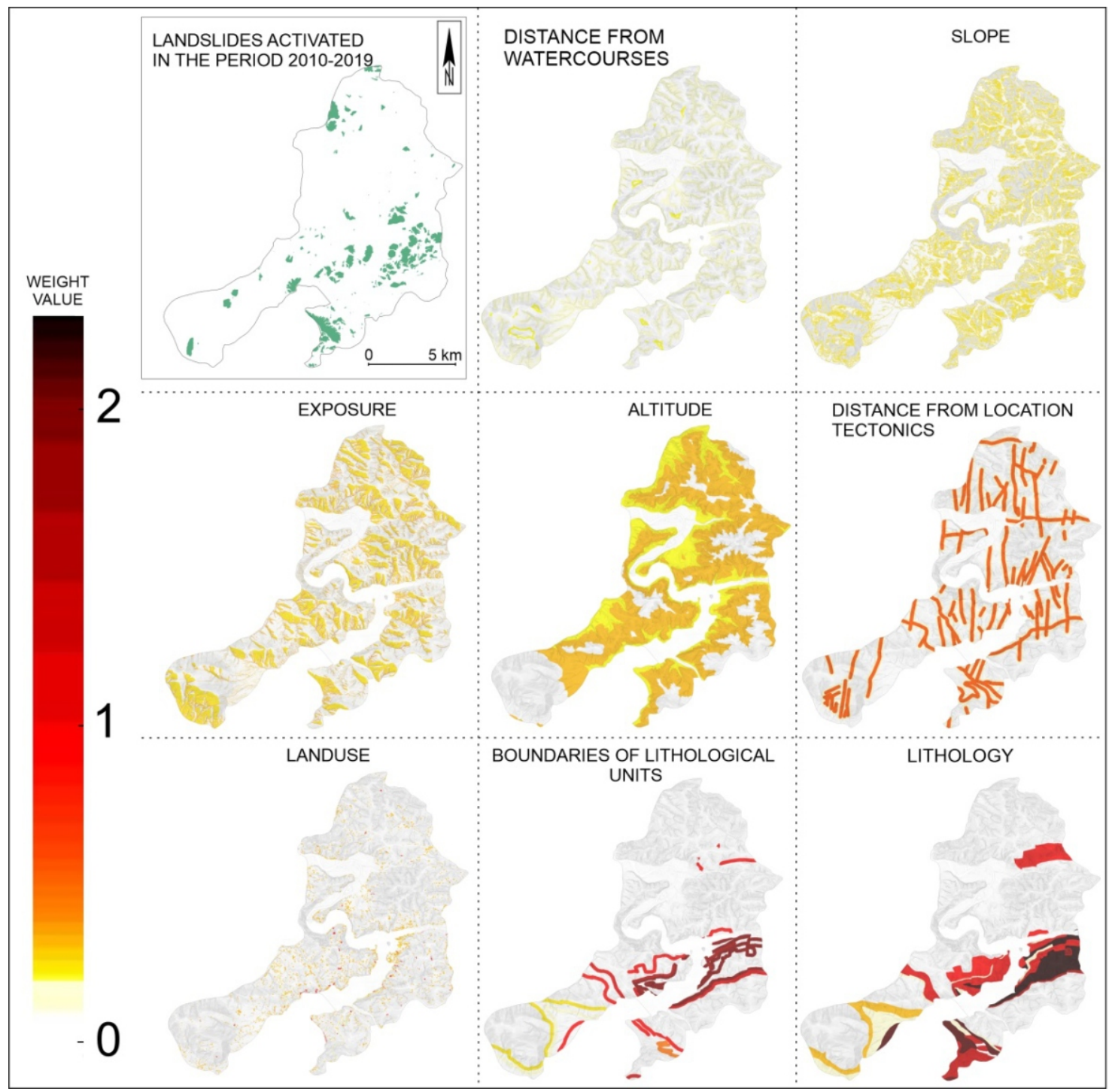

Fig. 16. Comparison of positive weighting values for individual passive factors 
Table 5

Ranking of the influence of particular classes of passive factors on the activation of landslides in the area of Rożnów Lake

\begin{tabular}{|c|c|c|}
\hline FACTOR & CLASS & WEIGHT \\
\hline LITHOLOGY & Hieroglyphic Beds (S) & 2.23520 \\
\hline LITHOLOGY & Inoceramus Beds (M) & 2.11535 \\
\hline LITHOLOGY & Cergowa sandstones $(\mathrm{G})$ & 2.06128 \\
\hline LITHOLOGY & sandstones - Menillite Beds (S) & 1.99866 \\
\hline BOUNDARIES OF LU & variegated shales - Ciężkowice sandstones (S) & 1.92758 \\
\hline BOUNDARIES OF LU & Hieroglyphic Beds - Menillite Beds (S) & 1.91007 \\
\hline BOUNDARIES OF LU & Hieroglyphic Beds - Ciężkowice sandstones (S) & 1.90648 \\
\hline BOUNDARIES OF LU & variegated shales - Hieroglyphic Beds (S) & 1.87511 \\
\hline BOUNDARIES OF LU & upper Istebna shales - variegated shales (S) & 1.50985 \\
\hline LITHOLOGY & shales - Menilite Beds (S) & 1.48414 \\
\hline BOUNDARIES OF LU & Krosno Beds - Cergowa sandstones (G) & 1.40041 \\
\hline LITHOLOGY & Krosno Beds (G) & 1.24202 \\
\hline BOUNDARIES OF LU & $\begin{array}{l}\text { shales (Menilite Beds) - sandstones and shales (Krosno Beds) } \\
(\mathrm{S})\end{array}$ & 1.07244 \\
\hline BOUNDARIES OF LU & shales (Cergowa Beds) - sandstones (Cergowa Beds) (Mi) & 1.05763 \\
\hline LITHOLOGY & Ciężkowice sandstones (S) & 1.02385 \\
\hline LITHOLOGY & shales (Cergowa Beds) (Mi) & 1.02354 \\
\hline LANDUSE & shrub vegetation & 0.99282 \\
\hline BOUNDARIES OF LU & upper Istebna sandstones - upper Istebna shales (S) & 0.96212 \\
\hline LITHOLOGY & upper Istebna shales (S) & 0.89469 \\
\hline BOUNDARIES OF LU & Inoceramus Beds - variegated shales (M) & 0.88569 \\
\hline BOUNDARIES OF LU & variegated shales - Zembrzyce Beds $(\mathrm{M})$ & 0.87632 \\
\hline EXPOSURE & W & 0.67404 \\
\hline DISTANCE FROM THE TECTONIC DISLOCATIONS & $<100 \mathrm{~m}$ & 0.56567 \\
\hline EXPOSURE & $\mathrm{S}$ & 0.51100 \\
\hline BOUNDARIES OF LU & Krosno Beds - Grybów Beds (G) & 0.49832 \\
\hline EXPOSURE & $\mathrm{E}$ & 0.33028 \\
\hline LITHOLOGY & Hieroglyphic Beds (M) & 0.31607 \\
\hline LANDUSE & building & 0.31516 \\
\hline ALTITUDE & $300-400 \mathrm{~m}$ a.s.l. & 0.31401 \\
\hline BOUNDARIES OF LU & Magura sandstones - Hieroglyphic Beds (M) & 0.24827 \\
\hline EXPOSURE & SW & 0.23737 \\
\hline SLOPE & $12-15^{\circ}$ & 0.23541 \\
\hline SLOPE & $9-12^{\circ}$ & 0.22010 \\
\hline DISTANCE FROM WATERCOURSES & $400-500 \mathrm{~m}$ & 0.20964 \\
\hline LANDUSE & roads & 0.20918 \\
\hline ALTITUDE & $<300 \mathrm{~m}$ a.s.l. & 0.20354 \\
\hline DISTANCE FROM THE TECTONIC DISLOCATIONS & $100-200 \mathrm{~m}$ & 0.19308 \\
\hline BOUNDARIES OF LU & Hieroglyphic Beds - variegated shales (M) & 0.17677 \\
\hline DISTANCE FROM WATERCOURSES & $<100 \mathrm{~m}$ & 0.16629 \\
\hline EXPOSURE & $\mathrm{N}$ & 0.14703 \\
\hline LITHOLOGY & variegated shales $(\mathrm{M})$ & 0.11239 \\
\hline SLOPE & $15-18^{\circ}$ & 0.08363 \\
\hline EXPOSURE & SE & 0.02378 \\
\hline LANDUSE & forests & 0.02249 \\
\hline EXPOSURE & NW & 0.01366 \\
\hline SLOPE & $6-9^{\circ}$ & 0.01065 \\
\hline BOUNDARIES OF LU & sandstones (Krosno Beds) - shales (Krosno Beds) & 0.00037 \\
\hline DISTANCE FROM THE TECTONIC DISLOCATIONS & $200-300 \mathrm{~m}$ & -0.00009 \\
\hline DISTANCE FROM WATERCOURSES & $300-400 \mathrm{~m}$ & -0.03005 \\
\hline LANDUSE & meadows and arable fields & -0.04309 \\
\hline DISTANCE FROM WATERCOURSES & $100-200 \mathrm{~m}$ & -0.08300 \\
\hline
\end{tabular}


Tabl. 5 cont.

\begin{tabular}{|c|c|c|}
\hline FACTOR & CLASS & WEIGHT \\
\hline LITHOLOGY & shales (Krosno Beds) (S) & -0.08495 \\
\hline SLOPE & $18-21^{\circ}$ & -0.08911 \\
\hline SLOPE & $<3^{\circ}$ & -0.12153 \\
\hline SLOPE & $>30^{\circ}$ & -0.14586 \\
\hline SLOPE & $21-24^{\circ}$ & -0.17986 \\
\hline BOUNDARIES OF LU & Zembrzyce Beds - Magura sandstones (M) & -0.18149 \\
\hline DISTANCE FROM THE TECTONIC DISLOCATIONS & $300-400 \mathrm{~m}$ & -0.19892 \\
\hline SLOPE & $24-27^{\circ}$ & -0.20886 \\
\hline DISTANCE FROM THE TECTONIC DISLOCATIONS & $400-500 \mathrm{~m}$ & -0.21692 \\
\hline SLOPE & $27-30^{\circ}$ & -0.23576 \\
\hline DISTANCE FROM WATERCOURSES & $200-300 \mathrm{~m}$ & -0.23944 \\
\hline LITHOLOGY & Zembrzyce Beds (M) & -0.26135 \\
\hline BOUNDARIES OF LU & Lower Istebna Beds - lower Istebna shales (Upper Istebna Beds) (S) & -0.26251 \\
\hline BOUNDARIES OF LU & over $100 \mathrm{~m}$ from the boundaries of lithological units & -0.27711 \\
\hline LAND USE & unclassified & -0.33175 \\
\hline SLOPE & $3-6^{\circ}$ & -0.34723 \\
\hline LAND USE & crops & -0.62120 \\
\hline EXPOSURE & NE & -0.63675 \\
\hline BOUNDARIES OF LU & $\begin{array}{c}\text { lower Istebna shales (Upper Istebna Beds) - upper Istebna sand- } \\
\text { stones (S) }\end{array}$ & -0.70233 \\
\hline LITHOLOGY & lower Istebna shales (Upper Istebna Beds) (S) & -0.94836 \\
\hline LITHOLOGY & Cergowa sandstones (Mi) & -0.95568 \\
\hline LITHOLOGY & Lower Istebna Beds (S) & -0.95616 \\
\hline LITHOLOGY & sandstones and shales - Krosno Beds (S) & -0.95870 \\
\hline LITHOLOGY & Godula Beds (S) & -1.00956 \\
\hline ALTITUDE & $400-500 \mathrm{~m}$ a.s.l. & -1.04583 \\
\hline LITHOLOGY & upper Istebna sandstones (S) & -1.05942 \\
\hline DISTANCE FROM THE TECTONIC DISLOCATIONS & $>500 \mathrm{~m}$ & -1.11776 \\
\hline LITHOLOGY & Grybów Beds (G) & -1.13649 \\
\hline ALTITUDE & 500-600 m a.s.I. & -1.16320 \\
\hline DISTANCE FROM WATERCOURSES & $500-600 \mathrm{~m}$ & -1.59229 \\
\hline LITHOLOGY & Magura sandstones $(\mathrm{M})$ & -2.15572 \\
\hline BOUNDARIES OF LU & Godula Beds - Lower Istebna Beds (S) & -2.36835 \\
\hline BOUNDARIES OF LU & Upper Istebna Beds - variegated shales (S) & -3.29839 \\
\hline BOUNDARIES OF LU & upper Istebna sandstones - Hieroglyphic Beds (S) & -3.85746 \\
\hline BOUNDARIES OF LU & upper Istebna shales - Ciężkowice sandstones (S) & -3.90161 \\
\hline BOUNDARIES OF LU & lower Istebna shales - Ciężkowice sandstones (S) & -4.41066 \\
\hline DISTANCE FROM WATERCOURSES & $>600 \mathrm{~m}$ & -4.80896 \\
\hline BOUNDARIES OF LU & upper Istebna sandstones - Ciężkowice sandstones (S) & -5.44666 \\
\hline BOUNDARIES OF LU & Lower Istebna Beds - Upper Istebna Beds (S) & -5.53058 \\
\hline ALTITUDE & $>700 \mathrm{~m}$ a.s.l. & -7.16917 \\
\hline ALTITUDE & $600-700 \mathrm{~m}$ a.s.I. & -8.37938 \\
\hline
\end{tabular}

LU - lithological unit; explanations as in Tables 1 and 2

was obtained for areas covered with shrub vegetation, followed by built-up areas with a value of 0.32 (Table 5). Despite these results, land cover seemed not to have been significant to the activation of landslides in the period 2010-2019. It is true that lower values for forested areas can be associated with reduced infiltration of water into the rock mass and a lower pressure of pore waters, but this is important only in areas of shallow landslides where the slip surface does not exceed 3 metres. More frequent landslide movements in places where shrubs occur are probably related to the occurrence of old, previously activated landslides, which resulted in e.g. abandonment of agricultural activity and no further development of the area. In this case, the occurrence of shrubbery is the result of the activation of the landslide, and not the other way around. The occurrence of buildings may be associated with the loading of slopes and with unregulated water management; however, the high value of the weighting for built-up areas may be associated with the activation of parts of large landslides within which there are buildings. An additional impact may be represented by the high population of the area of Znamirowice, Gródek nad Dunajcem and Przydonica, where there are many other landslide factors, including favourable lithology or tectonics.

A much more important factor seems to be tectonics, the influence of which on the development of landslides in the 


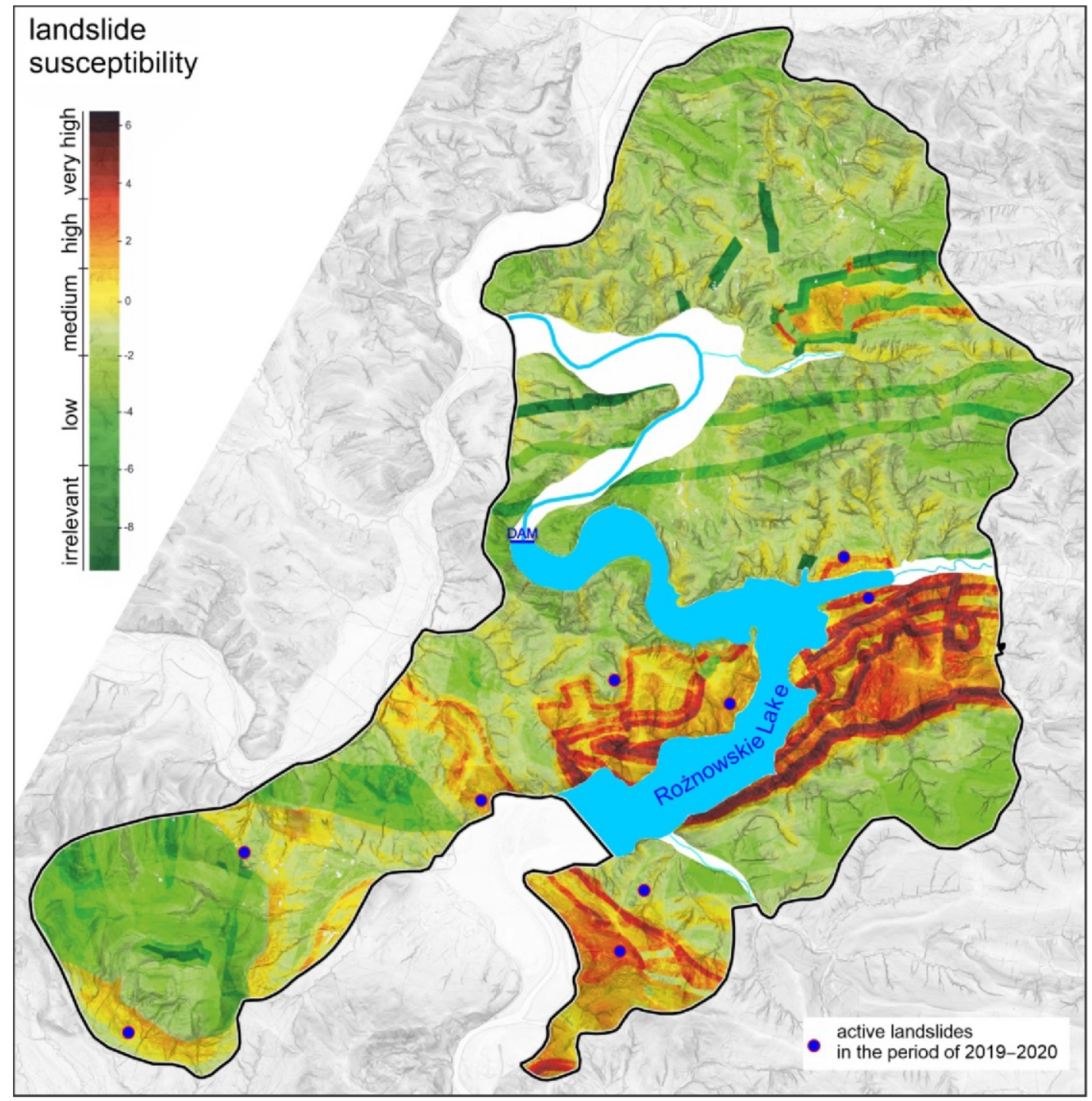

Fig. 17. Map of landslide susceptibility in the Rożnów Lake region

Rożnów Lake region was emphasized earlier. The weighting values decrease with increasing distance from faults and overthrusts. The most important influence is the direct vicinity (up to $100 \mathrm{~m}$ ) of the main tectonic dislocations, where the weighting is 0.56 . The importance of this factor is emphasized by areas more distant than $200 \mathrm{~m}$ from the tectonic dislocations having negative weightings (Table 5 ), which is clearly seen in Figure 16.

Altitude is another factor. The highest values were obtained for altitudes in the range of 300-400 m a.s.l. and below $300 \mathrm{~m}$ a.s.l., being respectively 0.31 and 0.2 . For areas located above $400 \mathrm{~m}$ a.s.I. there are negative values. This factor is largely correlated with lithology. The highest peaks are made of rocks more resistant to mass movements, e.g. the thick-bedded Magura sandstones, for which a negative value was also calculated.

Slope exposure turned out to be a less important factor. In this case, the highest values were obtained for the slopes descending to the W and SW s (Fig. 16 and Table 5). This reflects the greater amount of rainfall on the south-western slopes associated with the dominance of the western and southwestern winds.
Small weighting values were obtained for the slope factor (Fig. 16 and Table 5). The highest of these, of 0.24 , is characterized by slopes in the range of $12-15^{\circ}$. Positive weightings were obtained for slopes in the range of $6-8^{\circ}$. The steeper and gentler slopes showed negative values. A smaller impact on the development of landslides on steep slopes is associated with the rapid runoff of rainwater, and thus slower infiltration of water into the rock mass.

The least important factor in activating landslides turned out to be distances from watercourses (Fig. 16 and Table 5). Positive weightings were obtained only for the ranges of 400-500 m and $<100 \mathrm{~m}$ from surface waters. It should be noted here that the study does not take into account landslides with an area of $<0.03 \mathrm{ha}$, usually activated directly on stream slopes. Additionally, the entire areas of activated landslide were used for the calculations, even if only their lower part was activated.

On the basis of individual values of passive factors, the landslide susceptibility was calculated (Fig. 17). In order to eliminate the interdependent factors, a correlation matrix for all passive factors was prepared. Based on the data obtained, the absolute height factor was excluded, the value of which was the 
highest correlation with the lithology factor and was 0.34 . The results indicate the highest probability of new movements in the area of Znamirowice, Gródek nad Dunajcem, Przydonica, Zbyszyce, Łyczanka, Kłodne, and the areas NE of Roztoka-Brzeziny. The resulting map (Fig. 17) shows the regions most endangered by new activations, but it cannot be read uncritically, as the set of activated landslides used for vulnerability calculations accounts for $<20 \%$ of all landslides and may not give a full picture of the probability of future movements. Areas of old landslides, should be treated as places with at least an average degree of susceptibility to the occurrence of future movements. The lithological boundaries in the northern part of the research area cannot be considered, e.g. between the Godula and Istebna Beds, or the boundary between the Lower Istebna Beds and the Upper Istebna Beds, as areas with the lowest susceptibility to landslides, because the existence of this boundary probably does not reduce the likelihood of landslides being triggered relative to the neighboring area.

The map of landslide susceptibility was compared with the results of analyses from the latest flight, carried out in 2020. These data were not used to calculate the susceptibility map. Based on these data, it was found that 9 landslides were activated in the period 2019-2020. Seven of these were activated in places of high susceptibility (Fig. 17).

\section{DISCUSSION}

This study is the first in Poland to use Differential Digital Terrain Model analyses to determine the causes of landslide development across an extensive study area. A common problem in determining the causes of landslides is considering all landslides, even inactive ones. It is possible that some of these will not be reactivated in the absence of catastrophic events such as earthquakes or drastic climate changes. In some studies of small areas of the Carpathians only active landslides were taken into consideration (e.g., Kamiński, 2007; Mrozek, 2013), or landslide data was obtained in the field or the Polish SOPO database on landslides was used (e.g., Wojciechowski, 2019). These analyses show that field assessment of landslide activity is often subjective, especially when landslide activation occurred several years before the fieldwork (Wódka, 2020). Differential terrain models made it possible to focus only on landslides that were clearly activated in the last decade. Thus, it is possible to determine the causes of the present-day development of landslides, and so the threat associated with the current climatic conditions.

The "landslide catastrophe" that took place in 2010 would lead to the activation of about 790 landslides in the Rożnów Lake region. In later years, there was a clear decrease in landslide activity, reflected in both the number of activated forms and the volume of surface deformation resulting from mass movements (Table 4).

Analyses of DDMs showed that during or immediately after the 2010 "landslide catastrophe", the areas covered by some landslides increased and new landslide forms were created (Table 4). In most cases, this took place within sandstone outcrops, including that of the thick-bedded Ciężkowice sandstones. The significance of landslides involving the Ciężkowice sandstones in very rainy periods was consistent with calculations of the lithological displacement index. In the period 2010-2013, this formation had one of the highest average deformation volumes per $\mathrm{m}^{2}$

The development of landslides in these thick-bedded sandstones was caused by long-term rainfall that took place from the beginning of May to June 4, 2010. The highest amounts of rain- fall were recorded between May 15 and June 4, 2010. According to Institute of Meteorology and Water Management data from the nearest measurement station in Limanowa, $381 \mathrm{~mm}$ of rain fell then, and at the beginning of June, rainfall was intense, with a total of $147 \mathrm{~mm}$ in the last six days. These values are slightly lower than those reported by Gil (1997) who reported, on slopes with a predominance of sandstones, mass movements with rainfall of $400-550 \mathrm{~mm}$ occurring in $20-40$ days, the sum in the last 6 days exceeding $250 \mathrm{~mm}$.

Thirty-five days of rainfall (with two days break) with a total of $469 \mathrm{~mm}$ were needed to start several hundred deep landslides, both in shale and sandstones, in the area of Rożnów Lake. This is in line with the observations made by Starkel (1996) who suggested that deep landslides are triggered only after prolonged rainfalls of $100-500 \mathrm{~mm}$ a month.

Between 2011 and 2019 increase in landslide area or new landslide formation was rare (Table 4), with changes in the extent of landslides recorded on differential terrain models being developed thin-bedded flysch, mainly in sandstones and shales of the Hieroglyphic Beds.

The analyses show that only catastrophic precipitation is capable of triggering landslides within the local thick-bedded sandstones, but it is within these formations that the greatest deformation of the terrain and landslide size increase occur. The landslide susceptibility is therefore largely dependent on the climatic conditions. Slopes made of thick-bedded sandstones are generally less susceptible to landslides. However, in the case of catastrophic events (intense and prolonged rainfall, floods), they may turn out to be more susceptible to mass movements than slopes made of thin-bedded flysch.

This research clearly indicates that an important role in the development of landslides is played by the geological setting (lithology, faults, overthrusts) while other factors such as slope and exposure are of secondary importance. The statistical calculations also indicated that the presence of lithological contacts is an important factor. Until now, this factor was rarely taken into account in landslide susceptibility, though the relationship between the development of landslides and the presence of lithological contacts in the Polish Carpathians was previously noticed by Kotarba (1986), Wójcik (1997) and Długosz (2011)

Although studies in some parts of the world indicate that geology does not play a large role in calculations of landslide susceptibility (i.a., Jebur et al., 2014), this factor should not be ignored in such calculations, especially when they concern the Carpathian region, it dominates complex rock slides.

\section{CONCLUSIONS}

1. The most landslide-susceptible areas around the Rożnów Dam-Lake are the Hieroglyphic Beds of the Silesian Nappe, the Inoceramus Beds of the Magura Nappe, and the areas where variegated shale comes into contact with the Ciężkowice sandstones or Hieroglyphic Beds. The development of landslides can also be expected in the area of the Przydonica overthrust and the overthrusting of the Magura Nappe onto the Silesian and Grybów nappes.

2. The conditions for the development of landslides differ depending on the amount of precipitation. In less rainy periods, thin-bedded strata are of significant importance. In the event of catastrophic precipitation ( $380 \mathrm{~mm}$ in 20 days), slopes composed of thick-bedded deposits, especially the Ciężkowice sandstones, may turn out to be more susceptible.

3. Statistical analyses of the research area showed that the most susceptible areas to the activation of landslides are the 
southern and south-eastern parts of the study area in Gródek nad Dunajcem region.

4. A DDM from ALS data allows for objective determination of undisputedly active zones, which facilitates the analysis of the causes of the contemporary reactivation of landslides.

5. A DDM calculated from ALS data is a useful tool for tracking changes in landslide dynamics. Despite the accuracy limited by an error of $25-30 \mathrm{~cm}$, when correctly analysed, it allows identification of the main trends in the development of landslides across large areas.

6. Performing repeated ALS flights with an average density of $\sim 7$ points $/ \mathrm{m}^{2}$ makes it possible to track the activity of land- slides across large areas. The use of ALS data for statistical calculations gives a more complete picture of the contemporary landslide risk.

Acknowledgements. I would like to thank A. Wójcik and T. Wojciechowski (Polish Geological Institute - National Research Institute) for numerous discussions and support during the research work. I am grateful to the anonymous reviewers for their critical reading of the manuscript, and for remarks that significantly improved the paper.

\section{REFERENCES}

Ardizzone, F., Cardinali, M., Galli, M., Guzzetti, F., Reichenbach, P., 2007. Identification and mapping of recent rainfall induced landslides using elevation data collected by airborne LiDAR. Natural Hazards and Earth System Sciences, 7: 637-650.

Bąk, M., Długosz, M., Gorczyca, E., Kasina, K., Kozioł, T., Wrońska-Wałach, D., Wyderski, P., 2011. Mapa osuwisk i terenów zagrożonych ruchami masowymi. Gmina Łososina Dolna, in scale 1:10 000 (in Polish). Państwowy Instytut Geologiczny, Warszawa.

Bober, L., 1984. Landslide areas in the Polish Flysch Carpathians and their connection with the geological structure of the region (in Polish with English summary). Biuletyn Instytutu Geologicznego, 340: 115-158.

Bonham-Carter, G.F., Agterberg, F.P., Wright, D.F., 1989. Weights of evidence modelling: a new approach to mapping mineral potential. Geological Survey of Canada Paper, 89-9: 171-183.

Bonham-Carter, G.F., 1994. Geographic Information System for Geoscientists: Modelling with GIS. 1st edition. Pergamon Press, Ontario.

Borkowski, A., Perski, Z., Wojciechowski, T., Jóźków, G., Wójcik, A., 2011. Landslides mapping in Roznow lake vicinity, Poland using Airborne Laser Scanning data. Acta Geodynamica et Geomaterialia, 3: 325-333.

Borkowski, A., Perski, Z., Wojciechowski, T., Wójcik, A., 2012. LiDAR and SAR data application for landslide study in Carpathians region (Southern Poland). Proceedings of the XXII Congress of the International Society of Photogrammetry and Remote Sensing. Melbourne, 25 August - 1 September 2012 The Surveying and Spatial Sciences Institute of Australia, ISPRS.

Brabb, E.E., 1984. Innovative approaches to landslide hazard mapping. Proceedings of the 4th International Symposium on Landslides, Toronto, 1: 307-324.

Brezny, M., Pánek, T., 2017. Deep-seated landslides affecting monoclinal flysch morphostructure: evaluation of LiDAR derived topography of the highest range of the Czech Carpathians. Geomorphology, 285: 44-57.

Burns, W., Coe, J.A., Kaya, B.S., 2010. Analysis of elevation change detected from multi-temporal LiDAR surveys in forested landslide terrain in Western Oregon. Environmental \& Engineering Geoscience, 4: 315-341.

Burtan, J., Skoczylas-Ciszewska, K., 1964. Szczegółowa mapa geologiczna Polski w skali 1:50 000, arkusz Mecina (bez utworów czwartorzędowych) wydanie tymczasowe (in Polish) Instytut Geologiczny, Warszawa.

Burtan, J., Cieszkowski, M., Ślączka, A., Zuchiewicz, W., 1991. Szczegółowa mapa geologiczna Polski w skali 1:50 000, arkusz Męcina (in Polish). Państwowy Instytut Geologiczny, Warszawa.

Carrara, A., Guzzetti, F., Cardinali, M., Reichenbach, P., 1999. Landslide hazard evaluation: a review of current techniques and their application in multi-scale study, Central Italy. Geomorphology, 31: 181-216.

Carter, W., Shrestha, R., Tuell D., Bloomquist, D., Sartori M., 2001. Airborne laser swathmapping shines new light on earths topography. EOS, Transactions of American Geophysical Union, 82: 549-555.

Chiu, Ch.-L., Fei, L.-Y., Liu, J.-K., Wu, M.-CH., 2015. National airborne LiDAR mapping and examples for applications in deep-seated landslides in Taiwan. IEEE International Geoscience and Remote Sensing Symposium (IGARSS) 26-31, July 2015 Milan, Italy: 4688-4691.

Chowaniec, J. (ed.), Wójcik, A. (ed.), Mrozek, T., Rączkowski, W., Nescieruk, P., Perski, Z., Wojciechowski, T., Marciniec, P, Zimnal, Z., Granoszewski, W., 2012. Osuwiska W województwie małopolskim. Atlas-przewodnik (in Polish). Departament Środowiska, Rolnictwa i Geodezji Urzędu Marszałkowskiego Województwa Małopolskiego, Zespół Geologii, Kraków.

Cieszkowski, M., 1992. Michalczowa Zone - a new unit of the Fore-Magura Zone, West Carpathians, South Poland (in Polish with English summary). Geologia, 18: 1-125.

Cieszkowski, M., Koszarski, A., Leszczyński, S., Michalik, M., Radomski, A., Szulc, J., 1987. Szczegółowa mapa geologiczna Polski w skali 1:50 000, arkusz Ciężkowice (in Polish). Państwowy Instytut Geologiczny, Warszawa.

Cruden, D.M., Varnes, D.J., 1996. Landslides types and processes. Transportation Research Board, NRC Washington D.C., Special Report, 247: 36-75.

Daehne, A., Corsini, A., 2012. Kinematics of active earthflows revealed by digital image correlation and DEM subtraction techniques applied to multi-temporal LiDAR data. Earth Surface Processes and Landforms 38: 640-654.

Dikau, R., Brunsden, D., Schrott, L., Ibsen, M.L. (eds.), 1996. Landslide Recognition. Identification, Movement and Causes, J. Wiley \& Sons.

Długosz, M., 2011. Landslide susceptibility in the Polish Carpathians (in Polish with English summary). Prace Geograficzne IGiPZ PAN, 230: 1-112.

Galli, M., Ardizzone, F., Cardinali, M., Guzzetti, F., Reichenbach, P., 2008. Comparing landslide inventory maps. Geomorphology, 94: 268-289.

Gil, E., 1997. Meteorological and hydrological conditions of landslides, Polish Flysch Carpathians. Studia Geomorphologica Carpatho-Balcanica, 31: 143-157.

Glade, T., Crozier, M., 2005. A review of scale dependency in landslide hazard and risk analysis. In: Landslide Hazard and Risk (eds. T. Glade, M., Andreson and M. Crozier): 75-138. J. Wiley \& Sons, Chichester.

Glenn, N.F, Streutker, D.R., Chadwick, D.J., Thackray, G.D. Dorsch, S.J., 2006. Analysis of LiDAR-derived topographic in- 
formation for characterizing and differentiating landslide morphology and activity. Geomorphology, 73: 131-148.

Guzzetti, F., Cesare Mondini, A., Cardinali, M., Fiorucci, F., Santangelo, M., Chang, K.T., 2012. Landslide inventory maps: new tools for an old problem. Earth-Science Reviews, 112 : $42-66$.

Jaboyedoff, M., Oppikofer, T., Abellán, A., Derron, M.H., Loye, A., Metzger, R., Pedrazzini, A., 2012. Use of LiDAR in landslide investigations: a review. Natural Hazards, 61: 5-28.

Jebur, M.N., Pradhan, B., Tehrany, M.S., 2014. Optimization of landslide conditioning factors using very high-resolution Airborne Laser Scanning (LiDAR) data atcatchment scale. Remote Sensing of Environment, 152: 150-165.

Jodłowski, J., Dobosz, T,. Poroszewski, K., Winiecka, A., 2010. Mapa osuwisk i terenów zagrożonych ruchami masowymi. Gmina Limanowa, 1:10 000 (in Polish). Państwowy Instytut Geologiczny, Warszawa

Jurys, L., Woźniak, T., Małka, A., Rudeńska, W., Frydel, J., 2011. Mapa osuwisk i terenów zagrożonych ruchami masowymi. Gmina Zakliczyn, 1:10 000 (in Polish). Państwowy Instytut Geologiczny, Warszawa.

Kamiński, M., 2007. Landslide susceptibility map: a case study from the Jodłówka region (Dynowskie Foothills) (in Polish with English summary). Przegląd Geologiczny, 55: 779-784.

Koluch, Z., Nowicka, D., 2012. Mapa osuwisk i terenów zagrożonych ruchami masowymi. Gmina Chełmiec, skala 1:10 000 (in Polish). Państwowy Instytut Geologiczny, Warszawa.

Kotarba, A., 1986. The role of landslides in modelling of the Beskidian and Carpathian Foothills relief (in Polish with English summary). Przegląd Geograficzny, 58: 119-129.

Lato, M.J., Hutchinson, D.J., Gauthier, D., Edwards, T., Ondercin, M., 2014. Comparison of Airborne Laser Scanning, terrestrial laser scanning, and terrestrial photogrammetry for mapping differential slope change in mountainous terrain. Canadian Geotechnical Journal, 52: 1-12.

Lee, S., Choi, J., 2004. Landslide susceptibility mapping using GIS and the weight-of-evidence model. International Journal of Geographical Information Science, 18: 789-814.

Lee, S., Lee, M.J., Jung, H.S., 2017. Data mining approaches for landslide susceptibility mapping in Umyeonsan, Seoul, South Korea. Applied Sciences, 7: 683.

Liu, J, Duan, Z., 2018. Quantitative assessment of landslide susceptibility comparing statistical index, index of entropy, and weights of evidence in the Shangnan Area, China. Entropy, 20: 868.

Małka, A., 2021. Landslide susceptibility mapping of Gdynia using geographic information system-based statistical models. Natural Hazards, 107: 639-674.

Margielewski, W., 2004. Patterns of gravitational movements of rock masses in landslide forms of the Polish Flysch Carpathians (in Polish with English sumary). Przegląd Geologiczny, 52: 603-614.

McKean, J., Roering J., 2004. Objective landslide detection and surface morphology mapping using high-resolution airborne laser altimetry. Geomorphology, 57: 331-351.

Mickelson, K.A., 2011. LiDAR-based landslide inventory and susceptibility mapping, and differential LiDAR analysis for the Panther Creek, Watershed, Coast Range, Oregon. M.Sc. thesis, Portland State University, Portland.

Mora, O.E., Lenzano, M.G., Toth, Ch.K., Grejner-Brzezinska, D.A., Fayne, J., 2018. Landslide change detection based on multi-temporal airborne LiDAR-Derived DEMs. Geosciences, 8: $1-19$.

Mrozek, T., 2013. Landslide hazard and risk for a case-study of Szymbark region (Beskid Niski Mts) (in Polish with English summary). Prace Państwowego Instytutu Geologicznego, 199: $1-40$.

Paul, Z., 1997. Szczegółowa mapa geologiczna Polski w skali 1:50 000, arkusz Męcina (in Polish). Państwowy Instytut Geologiczny, Warszawa.
Pawłuszek, K., Borkowski, A. 2017a. Impact of DEM-derived factors and analytical hierarchy process on landslides sceptibility mapping in the region of Rożnów Lake, Poland. Natural Hazards, 86: 919-952.

Pawłuszek, K., Borkowski, A., 2017b. Automatic landslides mapping in the principal component domain. In: Advancing Culture of Living with Landslides (eds. M. Mikoś, V. Vilimek, Y. Yin and K. Sassa): 421-428. Landslides in Different Environments, Springer

Pawłuszek, K., Borkowski, A., 2020. Landslides identification using Airborne Laser Scanning data derived topographic terrain attributes and support vectormachine classification. The International Archives of the Photogrammetry, Remote Sensing and Spatial Information Sciences, 41-B8, 2016 XXIII ISPRS Congress, 12-19 July 2016, Prague, Czech Republic: 145-149.

Pawłuszek-Filipiak, K., Borkowski, A., 2020. On the importance of train-test split ratio of datasets in automatic landslide detection by supervised classification. Remote Sensing, 12: 1-33.

Perski, Z., Wojciechowski, T., Wójcik, A., Borkowski, A., 2014. Monitoring of landslide dynamics with LIDAR, SAR interferometry and photogrammetry case study of Kłodne Landslide, Southern Poland. Proceedings of World Landslide Forum, 3, 2-6 June 2014, Beijing 4: Discussion Session: 200-204.

Petschko, H., Bell, R., Glade, T., 2016. Effectiveness of visually analyzing LIDAR DTM derivatives for earth and debris slide inventory mapping for statistical susceptibility modeling. Landslides, 13: 857-872.

Pradhan, B., Oh, H.J., Buchroithner, M., 2010a. Weights-of-evidence model applied to landslide susceptibility mapping in a tropical hilly area Geomatics. Natural Hazards and Risk, 1: 199-223.

Pradhan, B., Youssef, A., Varathrajoo, R., 2010b. Approaches for delineating landslide hazard areas using different training sites in an advanced artificial neural network model. Geospatial Information Science, 13: 93-102.

Razak, K.A., Straatsma, M.W., Van Westen, C.J., Malet, J.P., De Jong, S.M., 2011. Airborne Laser Scanning of forested landslides characterization: terrain model quality and visualization. Geomorphology, 126: 186-200.

Schulz, W.H., 2004. Landslides mapped using LIDAR imagery, Seattle, Washington. U.S. Geological Survey Open-File Report 2004-1396: 1-11.

Sikora, R., Wojciechowski, T., 2019. Landslides in the Sudetes (in Polish with English summary). Przegląd Geologiczny, 67: 360-368.

Starkel, L., 1996. Geomorphic role of extreme rainfalls in the Polish Carpathians. Studia Geomorphologica Carpatho-Balcanica 30: 31-38.

Sutinen, R., Hyvönen, E., Kukkonen, I., 2014. LiDAR detection of paleolandslides in the vicinity of the Suasselkäpost glacial fault, Finnish Lapland. International Journal of Applied Earth Observation and Geoinformation, 27: 91-99.

Ślączka, A., Krugłov, S., Golonka, J., Oszczypko, N., Popadyuk, I., 2006. Geology and hydrocarbon resources of the Outer Carpathians, Poland, Slovakia and Ukraine: general geology. AAPG Memoir, 84: 221-258.

Van Den Eeckhaut, M., Poesen, J., Verstraeten, G., Vanacker, V., Nyssen, J., Moeyersons, J., Van Beek, L.P.H., Van Dekerckhove, L., 2007. Use of LIDAR-derived images for mapping old landslides under forest. Earth Surface Processes and Landforms, 32: 754-769.

Van Westen, C.J., Seijmonsbergen, A.C., Montavani, F., 1999. Comparing landslide hazard maps. Natural Hazards, 20: 137-158.

Van Westen, C.J., Rengers, N., Soeters, R., 2003. Use of geomorphological information in indirect landslide susceptibility assessment. Natural Hazards, 30: 399-419.

Van Westen, C.J., Castellanos, E., Kuriakose, S.L., 2008. Spatial data for landslide susceptibility, hazard, and vulnerability assesment. An overview. Engineering Geology, 102: 112-131. 
Varnes, D.J., 1978. Slope movement types and processes. Transportation Research Board, National Academy of Science, Washington, Special Report, 176: 11-33

Varnes, D.J., 1984. Landslide hazard zonation: a review of principles and practices. Natural Hazards, 3. United Nations Education, Scientific and Cultural Organization, Paris.

Ventura, G., Vilardo, G., Terranova, C., Bellucci Sessa, E., 2013. 4D Monitoring of active landslides by multi-temporal airborne LiDAR data. Landslide Science and Practice, 2: Early Warning, Instrumentation and Monitoring. Springer, Berlin.

Verbovsek, T., Kocevar, M., Benko, I., Macek, M., Petkovsek, A. 2017. Monitoring of the Stogovce Landslide slope movements with geasense GNSS probes, SW Slovenia. Advancing Culture of Living with Landslides: 3: 311-316. Springer International Publishing, Switzerland.

Wieczorek, D., Dąbrowski, R., Stoiński, A., 2010. Mapa osuwisk i terenów zagrożonych ruchami masowymi, gmina Czchów, skala 1:10 000 (in Polish). Państwowy Instytut Geologiczny, Warszawa.

Wojciechowski, T., 2019. Landslide susceptibility of Poland (in Polish with English summary). Przegląd Geologiczny 67: 320-325.

Wojciechowski, T., Pyrc, R., 2016. Czynniki wpływające na aktywność osuwisk w rejonie Gródka nad Dunajcem w 2010 roku (in Polish). III Polish Geological Congress. Conference materials: 432-434. Polish Geological Society.

Wojciechowski, T., Wójcik, A., 2015. Podatność i zagrożenia osuwiskowe na fragmencie wschodniego obrzeżenia Jeziora Rożnowskiego w świetle analiz różnicowych LIDAR (in Polish). Polish Conference Osuwisko, May 19-22 2015, Wieliczka. Conference materials: 79-81. Państwowy Instytut Geologiczny, Warszawa.

Wojciechowski, T., Borkowski, A., Perski, Z., Wójcik, A., 2012. Airborne Laser Scanning data in landslide studies at the example of the Zbyszyce landslide (Outer Carpathians) (in Polish with English summary). Przegląd Geologiczny, 60: 95-102.
Wódka, M., 2020. Assessment of activities of selected landslides in the Rożnów Dam Lake region based on field studies and analyses of Differential Digital Models (in Polish with English summary). Przegląd Geologiczny, 68: 60-68.

Wójcik, A., 1997. Landslides in the Koszarawa drainage basin structural and geomorphological control (Western Carpathians, Beskid Żywiecki Mts.) (in Polish with English summary). Biuletyn Państwowego Instytutu Geologicznego, 376: 5-42.

Wójcik, A., Perski, Z., Wojciechowski, T., 2012. Kłodne (in Polish). In: Osuwiska w województwie małopolskim. Atlas-przewodnik (eds J. Chowaniec and A. Wójcik). Departament Środowiska, Rolnictwa i Geodezji Urzędu Marszałkowskiego Województwa Małopolskiego, Zespół Geologii, Kraków.

Wójcik, A., Wojciechowski, T., Wódka, M., Krzysiek, U., 2015. Mapa osuwisk I terenów zagrożonych ruchami masowymi. gmina Gródek nad Dunajcem, skala 1:10 000 (in Polish). Państwowy Instytut Geologiczny, Warszawa.

Zabuski, L., Thiel, K., Bober, L., 1999. Osuwiska we fliszu polskich Karpat: geologia, modelowanie, obliczenia stateczności (in Polish). Institute of Hydro-Engineering of Polish Academy of Sciences, Gdańsk.

Ziętara, T., 1974. The role of landslides in modelling the Rożnów Foothills (Western Flysch Carpathians) (in Polish with English summary). Studia Geomorphologica Carpatho-Balcanica, 8: 115-133.

Zuchiewicz, W., 1990. Quaternary deposits of the Rożnów Foothills, Polish West Carpathians (in Polish with English summary). Przegląd Geologiczny, 38: 307-315.

Żytko, K., Zając, R., Gucik, S., Ryłko, W., Oszczypko, N., Garlicka, I., Nemćok, J., Elias, M., Mencik, E., Stranik, Z. 1989. Map of the tectonic elements of the Western Outer Carpathians and their foreland. In: Geological Atlas of the Western Outer Carpathians and Their Foreland (eds. D. Poprawa and J. Nemćok). Państwowy Instytut Geologiczny, Warszawa. 